\title{
Nutritional value of insects and ways to manipulate their composition
}

\author{
D.G.A.B. Oonincx ${ }^{1 *}$ and M.D. Finke ${ }^{2}$ \\ Animal Nutrition Group, Wageningen University and Research Centre, De Elst 1, 6708 WD Wageningen, the Netherlands; \\ Mark Finke LLC, 17028 E Wildcat Dr., Rio Verde, AZ 85263, USA; dennis.oonincx@wur.nl
}

Received: 5 June 2020 / Accepted: 3 September 2020

(c) 2020 Wageningen Academic Publishers

OPEN ACCESS@) REVIEW ARTICLE

\begin{abstract}
This article reports on the nutrients present in insects and factors affecting their variability. Data on protein content and amino acid profiles of a variety of insect species are discussed and their amino acid profiles compared to nutrient requirements of growing broiler chicks, catfish, trout, swine, and human adults and young children. Both in vitro and in vivo protein digestibility data for a variety of insect species is presented and factors affecting these data are discussed. Furthermore, the fat content and fatty acid profiles of a variety of insect species is reviewed, with special attention on omega- 6 and omega- 3 fatty acids. Information on carbohydrates, fibre and chitin in insects is shown along with potential effects on nutrient availability. This is followed by a discussion of essential minerals in insects with an emphasis on calcium and phosphorus. Data on insect vitamin content is shown along with a discussion of antinutritional factors such as phytate and thiaminase, which can adversely affect their nutritional value. Dietary effects on insect nutrient composition are reviewed with an emphasis on essential minerals, heavy metals, vitamin E, and carotenoids. Lastly, the effects of processing, including protein extraction and various cooking methods on insect composition are discussed. In summary, this article provides an overview of the nutrient content of insects, and how select nutrients can be altered.
\end{abstract}

Keywords: amino acids, fatty acids, vitamins, minerals, digestibility, nutrient manipulation

\section{Introduction}

Insects are important sources of nutrients for humans and a wide variety of other animal species. Hence studies on insect nutrient composition can be found in disciplines ranging from anthropology to zoology. Comprehensive literature reviews of insect nutrient content have been published (Bukkens, 1997; Finke, 2004; Payne et al., 2016; Raubenheimer and Rothman, 2013; Rumpold and Schluter, 2013a). While the first mention of using insects to feed production animals was in 1919 (Linder, 1919), it was not until the 1960s and 1970s that research started in earnest (Calvert et al., 1969; Hale, 1973; Teotia and Miller, 1973, 1974; Ueckert et al., 1972). The renewed interest in this area of study in the last decade yields numerous papers and comprehensive reviews regarding the safety of insects as food and feed, as well as several overviews of feeding trials for production animals (Gasco et al., 2019; Henry et al., 2015; Makkar et al., 2014; Riddick, 2014; Rumpold and Schluter, 2013b; Sanchez-Muros et al., 2014, 2016). Given the comprehensive nature of these recent reviews, this article will summarise this compositional data, focus on nutrients that have received little attention and nutrient manipulation. Data on both wild and produced insects is discussed.

\section{Nutrient content of insects}

\section{Protein and amino acids}

The protein content of insects varies between 25 and $75 \%$ on a dry matter (DM) basis (Barker et al., 1998; Bukkens, 1997; Cerda et al., 2001; Finke, 2002, 2013, 2015a; Oonincx and Dierenfeld, 2012; Oonincx and Van der Poel, 2011). Proteins are composed of amino acids and the true protein content equals the sum of amino acids. However, protein content is generally estimated by multiplying nitrogen content with a protein factor $(\mathrm{Kp})$ of 6.25 . This results in the so-called crude protein content. This factor is underestimated if not all amino acids are quantified, or due to methodological issues (Oonincx et al., 2019b), such as losses of amino acids during hydrolysis. Conversely, the presence of nonprotein 
nitrogen from compounds, such as chitin, uric acid, and $\beta$-alanine leads to overestimations of true protein content when using this factor (Janssen et al., 2017). An alternative Kp of 4.76 for insects has been suggested based on amino acid data on larvae of yellow mealworms (Tenebrio molitor), lesser mealworms (Alphitobius diaperinus) and black soldier flies (Hermetia illucens) (Janssen et al., 2017). Recalculating the data from 20 insect samples including 13 species and different developmental stages, results in an average Kp of 5.81; range 4.56 to 6.45 (Finke, 2002, 2007, 2013, 2015a,b). This data confirms that a Kp of 6.25 is often a slight overestimate. However, until data for more species and at different life stages are accumulated, retaining a Kp of 6.25 can be beneficial to facilitate comparisons between studies.

The amino acids that make up true protein, are generally grouped as either nutritionally indispensable (essential) amino acids or nutritionally dispensable (non-essential) amino acids. While all amino acids are required, nutritionally indispensable amino acids cannot be synthesised by most animal species and must be provided in the diet. Variation in amino acid patterns between life stages of a species partially depends on whether that species undergoes complete metamorphosis (holometabolous) or incomplete metamorphosis (hemimetabolous) (Finke, 2002; Pieterse and Pretorius, 2014). Comparison of the amino acid pattern (mg amino acid/g crude protein) for the hemimetabolous house cricket (Acheta domesticus) suggests that amino acid composition is fairly constant and unaffected by diet or life stage (Table 1). Similarly, black soldier fly prepupae raised on eight different diets had similar amino acid patterns (Spranghers et al., 2017; Wang et al., 2020), as did tobacco hornworm larvae (Manduca sexta) fed two different diets (Landry et al., 1986). This suggests that for holometabolous species amino acid patterns are fixed within a specific life stage. Body parts, such as wings, legs or mandibles, have specific physical requirements to function properly; therefore, it is unlikely that their amino acid composition can be altered by diet. Amino acid patterns between different life stages of holometabolous insects would however be expected to differ because larvae and adults are morphologically dissimilar. This was confirmed for yellow mealworms, where the amino acid pattern for larvae differed from the harder bodied adults (Finke, 2002). The adults contain more glycine (52\%) and tryptophan (37\%) than mealworm larvae, while larvae contain more leucine (29\%), phenylalanine (35\%) and tyrosine (120\%) than adults (Finke, 2002). The amino acid patterns of larvae and pupae meal of the house fly (Musca domestica) raised on the same diet also differ (Pieterse and Pretorius, 2014). In this case differences were seen for the amino acids alanine, arginine, aspartic acid, methionine, serine, and tyrosine.

Amino acid patterns are important because they partially determine the suitability of dietary protein sources. This suitability also depends on the amino acid requirements of the consuming animal. The amino acid with the lowest concentration relative to the requirement of the animal is called the first limiting amino acid. Table 2 shows the amino acid pattern of four commonly raised insect species and compares them to the amino acid requirements of broiler chicks, catfish, trout, swine, and adult humans and young children (NRC, 1994, 2011, 2012; WHO/FAO/UNU, 2007). Methionine and cystine are usually the first limiting amino acids in most insect species when fed to production animals or humans. The exception appears to be house crickets for catfish and swine, where threonine and/or tryptophan are first limiting. These calculations are supported by data from animal feeding trials. Methionine and arginine are the first limiting amino acids for broiler chicks when fed Mormon cricket meal (Anabrus simplex) as the sole source of dietary protein in purified diets (Finke et al., 1985), or when house cricket meal is the source of protein in a corn based diet (Nakagaki et al., 1987). Similarly, methionine is the first limiting amino acid in a corn-soy-meat meal diet for growing chickens when dried maggot meal substitutes for meat meal (Bamgbose, 1999). Methionine is also the first limiting amino acid when adult Mormon cricket meal (Finke et al., 1987), yellow mealworm larvae meal (Goulet et al., 1978), or house fly larvae meal are fed to growing rats (Onifade et al., 2001). The high amino acid scores of all four insect species for both children and adults suggests they are a high-quality protein source for humans.

Protein quality is also determined by digestibility and hence amino acid availability. Amino acids from insect meals are readily available when fed to poultry with values equal to, or higher than, those from conventional protein sources, such as soybean meal or fish meal (Table 3 ). The only exception is black solder fly larvae meal which has lower amino acid digestibilities especially for the sulphur containing amino acids, methionine and cystine (DeMarco et al., 2015; Schiavone et al., 2017). Larvae (Liland et al., 2017; Schmitt et al., 2019; Tschirner et al., 2015) and prepupae (Spranghers et al., 2017; Wang et al., 2020) of this species have a highly variable mineral content, which is influenced by their diet. As some protein is bound to their mineralised exoskeleton, an increased mineral content might decrease their digestibility. Therefore, amino acid and protein digestibility in poultry might be increased by raising this species on diets with a lower mineral content. Animal performance metrics and insect meal digestibility in shrimp, poultry, ducks, quail, pigs, rabbits, and various species of fish has been elaborately reviewed by Gasco et al. (2019).

In a monogastric digestibility model the in vitro protein digestibility for dried (conditions unknown) and milled larvae of the yellow mealworm and black soldier fly was only $65.5-68.7 \%$ (Marono et al., 2015). Similarly low values were obtained for raw house crickets $(65.5 \%)$ and 
Table 1. Amino acid patterns ( $\mathrm{mg} / \mathrm{g}$ crude protein) of house crickets (Acheta domesticus). ${ }^{1}$

\begin{tabular}{|c|c|c|c|c|c|c|c|c|c|c|}
\hline Amino acid & $\begin{array}{l}\text { Finke } \\
(2002) \\
\text { nymphs }\end{array}$ & $\begin{array}{l}\text { Finke } \\
\text { (2007) } \\
\text { nymphs }\end{array}$ & $\begin{array}{l}\text { Finke } \\
\text { (2015b) } \\
\text { nymphs }\end{array}$ & $\begin{array}{l}\text { Finke } \\
(2002) \\
\text { adults }\end{array}$ & $\begin{array}{l}\text { Finke } \\
\text { (2007) } \\
\text { adults }\end{array}$ & $\begin{array}{l}\text { Yi et al. } \\
\text { (2013) } \\
\text { adults }\end{array}$ & $\begin{array}{l}\text { Bosch et } \\
\text { al. (2014) } \\
\text { adults }\end{array}$ & $\begin{array}{l}\text { Nakagaki } \\
\text { et al. } \\
\text { (1987) }\end{array}$ & $\begin{array}{l}\text { Poelaert et } \\
\text { al. (2018) } \\
\text { adults }\end{array}$ & $\begin{array}{l}\text { Köhler et } \\
\text { al. (2019) } \\
\text { adults }\end{array}$ \\
\hline Alanine & 89.0 & 101.1 & 90.9 & 87.8 & 76.9 & 81.0 & 83.6 & 95.0 & 65.7 & 82.6 \\
\hline Arginine & 61.0 & 70.9 & 78.8 & 61.0 & 57.3 & 65.0 & 56.8 & 60.0 & 63.2 & 64.4 \\
\hline Aspartic acid & 70.8 & 79.4 & 82.4 & 83.9 & 84.9 & 76.0 & 76.4 & 88.0 & 71.0 & 103.5 \\
\hline Cystine & 8.4 & 9.1 & 9.8 & 8.3 & 9.8 & NR & 11.2 & NR & 12.9 & 9.1 \\
\hline Glutamic acid & 103.9 & 117.1 & 114.5 & 104.9 & 104.4 & 110.0 & 105.9 & 117.0 & 98.1 & 94.8 \\
\hline Glycine & 52.6 & 60.6 & 53.5 & 50.7 & 45.3 & 51.0 & 51.3 & 59.0 & 45.5 & 48.1 \\
\hline Histidine & 22.1 & 25.7 & 22.1 & 23.4 & 22.7 & 21.0 & 33.9 & 26.0 & 31.3 & 21.7 \\
\hline Isoleucine & 42.9 & 40.6 & 40.3 & 45.9 & 36.4 & 36.0 & 40.0 & 42.0 & 39.3 & 38.6 \\
\hline Leucine & 95.5 & 72.6 & 70.9 & 100.0 & 66.7 & 66.0 & 66.4 & 73.0 & 63.1 & 75.7 \\
\hline Lysine & 53.9 & 62.3 & 57.9 & 53.7 & 51.1 & 53.0 & 58.0 & 56.0 & 57.1 & 55.8 \\
\hline Methionine & 13.0 & 15.4 & 16.6 & 14.6 & 19.6 & NR & 15.8 & 15.0 & 18.7 & 15.2 \\
\hline Phenylalanine & 27.9 & 32.0 & 35.6 & 31.7 & 30.2 & NR & 31.8 & 22.0 & 31.7 & 36.0 \\
\hline Proline & 55.2 & 61.1 & 59.8 & 56.1 & 54.2 & 54.0 & 54.4 & 62.0 & 51.6 & 50.8 \\
\hline Serine & 41.6 & 42.9 & 40.4 & 49.8 & 52.0 & 38.0 & 37.1 & 49.0 & 46.2 & 59.4 \\
\hline Threonine & 35.7 & 38.9 & 37.6 & 36.1 & 31.1 & 35.0 & 36.2 & 35.0 & 38.5 & 39.7 \\
\hline Tryptophan & 5.2 & 6.3 & 8.7 & 6.3 & 7.6 & 9.0 & NR & 6.0 & 8.5 & 9.8 \\
\hline Tyrosine & 55.2 & 62.9 & 64.8 & 48.8 & 44.0 & NR & 62.1 & 41.0 & 47.4 & 95.7 \\
\hline Valine & 49.4 & 60.0 & 59.6 & 52.2 & 48.4 & 55.0 & 57.2 & 60.0 & 52.0 & 64.0 \\
\hline
\end{tabular}

yellow mealworms $(72.5 \%)$ in a porcine model, these were, however, similar to those for beef muscle and chicken breast (Poelaert et al., 2017). Oven cooking or autoclaving further decreased the in vitro digestibility of both house crickets and yellow mealworms and also increased neutral detergent fibre, but not acid detergent fibre (Poelaert et al., 2017). Kiiru et al. (2020) also reports very low in vitro protein digestibility values for raw (29-30.0\%) and extruded (38$50 \%$ ) cricket flours using a static method and quantifying the free amino acids. The latter quantification method is likely to underestimate digestibility as di- and tri-peptides would incorrectly be deemed indigestible. Conversely, higher in vitro protein digestibilities (76.4 to 93.3\%) were reported for 11 species of freeze-dried insects in a canine model (Bosch et al., 2014, 2016). This included house crickets (91.7\%), yellow mealworms (91.3-92.5\%), black soldier fly larvae (89.7\%) and black soldier fly pupae (77.7\%). The in vitro protein digestibility of raw yellow mealworms $(85.0 \%)$ was increased by vacuum cooking (90.5\%), boiling (90.1\%), oven cooking for 15 and 30 minutes (91.5 and 90.4\%, respectively), while frying (87.2\%) had no effect (Megido et al., 2018). Kinyuru et al. (2010a) also obtained high in vitro protein digestibilites (82.3 to 90.5\%) for freshly caught termites (Macrotermes subhylanus) and grasshoppers (Ruspolia differens) that declined slightly after solar drying at approximately $30^{\circ} \mathrm{C}$. Using two different methods, high in vitro protein digestibilities were also reported for yellow mealworm meal (90.2\%), and black soldier fly larvae meal (93-94\%), when extruded with wheat flour (Azzollini et al., 2018; Ottoboni et al., 2018). The high variability between the aforementioned studies suggest that in vitro protein digestibility data should be viewed with caution until it is correlated to in vivo studies. Processing and drying methods, as well as the used digestibility model, can have a large impact on data obtained in vitro.

Most amino acid availability data of insects pertain to poultry. However, numerous protein digestibility studies have been conducted in rats (Table 4). Typically, the milk protein casein is used as a benchmark in such studies. The digestibility of insect protein was in most cases equal to, or slightly lower, than that for casein. The lower values for protein digestibility in Table 4 for freeze dried yellow mealworms (Goulet et al., 1978), dried termites (Macrotermes falciger) (Phelps et al., 1975), and silkworm (Bombyx mori) pupae (Rao, 1994) are for apparent digestibility. True digestibility values are higher because they are corrected for endogenous protein/nitrogen losses. True protein digestibility is $7-15 \%$ higher than apparent protein digestibility in dried honey bees (Apis melifera) (Ozimek et al., 1985), crickets (Poelaert et al., 2018), yellow mealworms (Jensen et al., 2019; Poelaert et al., 2018) and lesser mealworms (Jensen et al., 2019). Rats fed silkworm pupae consumed $33 \%$ less feed than those fed casein, which 
Table 2. Amino acid patterns (mg/g crude protein) of four commonly raised insects and amino acids scores and first limiting amino acid for various species. ${ }^{1}$

\begin{tabular}{|c|c|c|c|c|}
\hline Amino acid & $\begin{array}{l}\text { Acheta domesticus } \\
\text { adults/nymphs }\end{array}$ & $\begin{array}{l}\text { Tenebrio molitor } \\
\text { larvae }\end{array}$ & $\begin{array}{l}\text { Zophobas morio } \\
\text { larvae }\end{array}$ & $\begin{array}{l}\text { Hermetia illucens } \\
\text { larvae/prepupae }\end{array}$ \\
\hline Alanine & 87.8 & 80.2 & 72.7 & 62.7 \\
\hline Arginine & 65.7 & 60.0 & 57.4 & 52.8 \\
\hline Aspartic acid & 79.1 & 81.0 & 83.1 & 88.3 \\
\hline Glutamic acid & 109.2 & 112.1 & 127.0 & 103.7 \\
\hline Glycine & 52.3 & 53.1 & 48.7 & 55.0 \\
\hline Histidine & 22.8 & 30.2 & 31.1 & 32.4 \\
\hline Isoleucine & 40.3 & 46.1 & 46.9 & 43.3 \\
\hline Leucine & 78.6 & 84.9 & 80.4 & 69.9 \\
\hline Lysine & 55.3 & 55.4 & 54.6 & 59.1 \\
\hline Methionine & 15.8 & 13.3 & 12.2 & 18.8 \\
\hline Methionine + cystine & 24.9 & 23.3 & 21.8 & 24.4 \\
\hline Phenylalanine & 31.5 & 35.2 & 37.2 & 41.5 \\
\hline Phenylalanine + tyrosine & 87.5 & 102.6 & 108.4 & 112.3 \\
\hline Proline & 56.7 & 68.1 & 55.9 & 55.4 \\
\hline Serine & 44.1 & 47.2 & 44.1 & 38.3 \\
\hline Threonine & 35.7 & 40.3 & 39.9 & 39.0 \\
\hline Tryptophan & 7.2 & 10.5 & 11.4 & 15.1 \\
\hline Valine & 54.1 & 62.9 & 60.5 & 63.8 \\
\hline \multicolumn{5}{|c|}{ Amino acid score/first limiting amino acid: } \\
\hline \multicolumn{5}{|l|}{ Humans } \\
\hline Children & 96/Met+Cys & 90/Met+Cys & 84/Met+Cys & 94/Met+Cys \\
\hline Adults & 113/Met+Cys & 106/Met+Cys & 99/Met+Cys & 111/Met+Cys \\
\hline \multicolumn{5}{|l|}{ Livestock } \\
\hline Poultry & 64/Met+Cys & $60 /$ Met+Cys & 56/Met+Cys & 62/Met+Cys \\
\hline Catfish & 55/Thr+Try & 54/Met+Cys & 50/Met+Cys & $56 /$ Met+Cys \\
\hline Trout & $52 /$ Met+Cys & 49/Met+Cys & 46/Met+Cys & $51 /$ Met+Cys \\
\hline Swine & $59 /$ Try & $56 /$ Met+Cys & $52 /$ Met+Cys & $58 /$ Met+Cys \\
\hline
\end{tabular}

Table 3. Low, high, and mean amino acid digestibilities (\%) of various insect meals when fed to poultry.

$\begin{array}{lllll}\text { Species and life stage } & \text { Low } & \text { High } & \text { Mean } & \text { Study } \\ \text { Gryllus testaceus adults } & 85 \text { (Cys) } & 96 \text { (Ala) } & 93 & \text { Wang et al. (2005) } \\ \text { Acrida cinerea adults } & 85 \text { (Cys) } & 99(\text { Thr) } & 94 & \text { Wang et al. (2007) } \\ \text { Musca domestica larvae } & 92 \text { (lle) } & 98 \text { (Lys) } & 95 & \text { Hwangbo et al. (2009) } \\ \text { M. domestica larvae } & 83 \text { (Gly) } & 96 \text { (Tyr) } & 91 & \text { Pieterse and Pretorius (2014) } \\ \text { M. domestica pupae } & 86 \text { (Ala) } & 100 \text { (Ser+Asp) } & 95 & \text { Pieterse and Pretorius (2014) } \\ \text { M. domestica larvae } & 77 \text { (Gly) } & 91 \text { (Tyr) } & 83 & \text { Hall et al. (2018) } \\ \text { Tenebrio molitor larvae } & 80 \text { (Met) } & 93 \text { (Ala) } & 86 & \text { DeMarco et al. (2015) } \\ \text { Hermetia illucens pupae } & 42 \text { (Met) } & 89 \text { (Pro) } & 68 & \text { DeMarco et al. (2015) } \\ \text { H. illucens larvae } & 44 \text { (Cys) } & 92 \text { (Ala+Tyr) } & 77 & \text { Schiavone et al. (2017) } \\ \text { H. illucens larvae } & 45 \text { (Cys) } & 99 \text { (Ala) } & 80 & \text { Schiavone et al. (2017) }\end{array}$


Table 4. True protein digestibility (\%) of various insect species, stages and process methods when fed to rats, compared to benchmark values for protein digestibility of casein. ${ }^{1}$

\begin{tabular}{|c|c|c|c|c|c|}
\hline Order & Species and life stage & $\begin{array}{l}\text { Protein } \\
\text { digestibility }\end{array}$ & Processing method & $\begin{array}{l}\text { Casein } \\
\text { benchmark }\end{array}$ & Study \\
\hline \multirow[t]{16}{*}{ Coleoptera } & Tenebrio molitor larvae meal ${ }^{*}$ & 75.1 & freeze dried & 88.4 & Goulet et al. (1978) \\
\hline & T. molitor larvae meal + methionine* & 78.9 & freeze dried & 88.4 & Goulet et al. (1978) \\
\hline & T. molitor larvae meal & 91.9 & freeze dried & 98.8 & Poelaert et al. (2018) \\
\hline & T. molitor larvae meal & 92.0 & freeze dried & ND & Jensen et al. (2019) \\
\hline & Alphitobius diaperinus larvae meal & 93.7 & freeze dried & ND & Jensen et al. (2019) \\
\hline & A. diaperinus larvae meal & 92.5 & dried at $120-160^{\circ} \mathrm{C}$ & ND & Jensen et al. (2019) \\
\hline & A. diaperinus larvae meal & 91.5 & vacuum dried at $40^{\circ} \mathrm{C}$ & ND & Jensen et al. (2019) \\
\hline & A. diaperinus larvae meal & 94.2 & defatted then dried & ND & Jensen et al. (2019) \\
\hline & A. diaperinus larvae meal & 91.4 & extruded then dried at $120^{\circ} \mathrm{C}$ & ND & Jensen et al. (2019) \\
\hline & A. diaperinus larvae meal & 92.4 & freeze dried with enzymes added & ND & Jensen et al. (2019) \\
\hline & Rhynchophorus phoenicis larvae & 91.8 & raw & 92.6 & Ekpo (2011) \\
\hline & R. phoenicis larvae & 92.6 & boiled & 92.6 & Ekpo (2011) \\
\hline & R. phoenicis larvae & 92.1 & fried & 92.6 & Ekpo (2011) \\
\hline & Oryctes rhinoceros larvae & 89.3 & raw & 92.6 & Ekpo (2011) \\
\hline & O. rhinoceros larvae & 90.1 & boiled & 92.6 & Ekpo (2011) \\
\hline & O. rhinoceros larvae & 89.7 & fried & 92.6 & Ekpo (2011) \\
\hline \multirow[t]{2}{*}{ Diptera } & Musca domestica larvae meal* & 90.6 & dried at $65^{\circ} \mathrm{C}$ & 93.3 & Iñiguez-Covarrubias et al. (1994) \\
\hline & M. domestica larvae meal & $89.0-91.0$ & unknown & $89.0-91.0$ & Kouamé et al. (2011) \\
\hline \multirow[t]{2}{*}{ Hymenoptera } & dried Apis mellifera adults & 71.5 & dried at $70^{\circ} \mathrm{C}$ & 96.8 & Ozimek et al. (1985) \\
\hline & A. mellifera adult concentrate & 94.3 & alkaline extraction of bees dried at $70^{\circ} \mathrm{C}$ & 96.8 & Ozimek et al. (1985) \\
\hline \multirow[t]{4}{*}{ Isoptera } & Macrotermes falciger meal ${ }^{*}$ & $45.3-50.7$ & dewinged, dried and lightly fried & 84.2 & Phelps et al. (1975) \\
\hline & Macrotermes bellicosus adults & 90.2 & dewinged, raw & 92.6 & Ekpo (2011) \\
\hline & M. bellicosus adults & 91.0 & dewinged, boiled & 92.6 & Ekpo (2011) \\
\hline & M. bellicosus adults & 90.9 & dewinged, fried & 92.6 & Ekpo (2011) \\
\hline \multirow[t]{11}{*}{ Lepidoptera } & Bombyx mori chrysalid meal & 88.9 & dried, conditions unknown & 99.8 & Lin et al. (1983) \\
\hline & B. mori chrysalid meal & 89.4-89.8 & dried, conditions unknown, water extracted & 99.8 & Lin et al. (1983) \\
\hline & B. mori pupae meal * & 67.0 & unknown & 84.0 & Rao (1994) \\
\hline & Samia ricinii pupae meal & 87.0 & dried at $60-70^{\circ} \mathrm{C}$ and defatted & 92.0 & Longvah et al. (2011) \\
\hline & S. ricinii pupae meal & 87.0 & dried at $60-70^{\circ} \mathrm{C}$ and defatted & 92.0 & Longvah et al. (2011) \\
\hline & Imbrasia belina larvae meal & 85.5 & $\begin{array}{l}\text { gastrointestinal contents removed then } \\
\text { dried. drying conditions unknown }\end{array}$ & 98.0 & Dreyer and Wehmeyer (1982) \\
\hline & I. belina larvae meal & 83.9 & $\begin{array}{l}\text { gastrointestinal contents removed then } \\
\text { dried. drying conditions unknown then } \\
\text { soaked in water and canned }\end{array}$ & 98.0 & Dreyer and Wehmeyer (1982) \\
\hline & I. belina larvae & 86.0 & raw & 92.6 & Ekpo (2011) \\
\hline & I. belina larvae & 88.4 & boiled & 92.6 & Ekpo (2011) \\
\hline & I. belina larvae & 87.8 & fried & 92.6 & Ekpo (2011) \\
\hline & Clanis bilineata larvae meal & 95.8 & heads removed and dried at $60^{\circ} \mathrm{C}$ & 96.1 & Xia et al. (2012) \\
\hline Orthoptera & Acheta domesticus meal & 83.9 & freeze dried & 98.8 & Poelaert et al. (2018) \\
\hline
\end{tabular}

would negatively affect apparent protein digestibility (Rao, 1994). Other studies using silkworm meal obtained much higher protein digestibility values. This suggests these low values are not representative. The wide range of protein digestibilities of insects when fed to rats is likely a function of species and life stage, but also how the material was processed prior to use in feeding trials.
Protein digestibility of insects is generally high and influenced by the following factors: (1) if a larger proportion of amino acids is present in cuticular proteins complexed with chitin, or is highly sclerotised protein digestibility is likely decreased (Finke, 2007; Ozimek et al., 1985); (2) removing certain body parts (typically wings, or heads) before further processing and feeding to rats increases 
between study variability; (3) processing methods such as drying can decrease protein digestibility depending on time and temperature (Dreyer and Wehmeyer, 1982; Pieterse and Pretorius, 2014).

\section{Fats and fatty acids}

The fat content of insects varies between 10 and $70 \%$ on a dry matter basis (Bukkens, 1997; Finke, 2013; Yang et al., 2006). Fat content is typically estimated by an extraction which determines the total weight of all fat-soluble molecules (crude fat). This includes glycerides but also waxes, sterols, fat soluble vitamins and other fat-soluble compounds.

Fat is composed of fatty acids. Two or three fatty acids are coupled to glycerol and form diglycerides and triglycerides, respectively. These fatty acids are divided into saturated, mono-unsaturated, and poly-unsaturated fatty acids based on their degree of saturation. Poly-unsaturated fatty acids are subdivided into omega 3, 6 or 9 poly-unsaturated fatty acids, based on the relative position of the first double bond.

The fatty acid composition of insects depends on the species and life stage as well as environmental factors such as diet, temperature, and light (Finke and Oonincx, 2017). Males of most species have smaller fat reserves than females (Kulma et al., 2019; Lease and Wolf, 2011; Liu et al., 2017; Nestel et al., 2005; Rho and Lee., 2014; Zhou et al., 1995). Commercially produced insects seem to have a higher fat content than those collected from the wild (Finke, 2002, 2013; Lease and Wolf, 2011; Oonincx and Dierenfeld, 2012; Yang et al., 2006). This might be due to decreased energy expenditure in captivity, ready access to diets with a high energy content, or both.

In general, wild caught insects contain relatively high amounts of linoleic acid (18:2 n-6) and linolenic acid (18:3 n-3) (Fast, 1970; Thompson, 1973). Commercially raised insects also contain high levels of linoleic acid but much lower levels of linolenic acid than wild caught insects, because their diet often contains large amounts of grains and grain by-products, which have low levels of linolenic acid (Dreassi et al., 2017; Finke, 2002, 2013; Jones et al., 1972; Oonincx et al., 2015b, 2019a; Paul et al., 2017). Larvae of the black soldier fly have an unusual fatty acid profile rich in lauric acid (C12:0) irrespective of the diet (Finke 2013; Oonincx et al., 2015a; Spranghers et al., 2017; St-Hilaire et al., 2007; Surendra et al., 2016). Like vertebrates, most insects can synthesise saturated and monounsaturated fatty acids (Beenakkers et al., 1985, Tietz and Stern, 1969). However, most species are unable to synthesise linoleic acid and linolenic acid, which makes those essential nutrients. There are exceptions such as the American cockroach (Periplaneta americana) and the house cricket, which apparently can synthesise these fatty acids (Borgeson and Blomquist, 1993; Borgeson et al., 1991).

In three insect species with an aquatic larval stage, the concentration of linolenic acid increased, while arachidonic acid (20:4n-6), and eicosapentaenoic acid (20:5 n-3) decreased in the adults after they emerged from their aquatic habitat (Hanson et al., 1985). This is likely due to differences in the fatty acid content of their diets. Several studies reporting on the fatty acid content of field collected insects find higher levels of eicosapentaenoic acid in aquatic species than in terrestrial species, which rarely contain these fatty acids (Fontaneto et al., 2011; Ghioni et al., 1996; Sushchik et al., 2003, 2013;). In aquatic ecosystems certain microalgae produce eicosapentaenoic acid, which is transferred to higher trophic levels including insects (Gladyshev et al., 2011). Eicosapentaenoic acid is not produced by higher plants in terrestrial ecosystems, therefore herbivorous terrestrial insects are less likely to obtain this fatty acid.

\section{Carbohydrates}

In general, carbohydrates calculated as nitrogen free extract, are present in small amounts in insects (Barker et al., 1998; Finke, 2002, 2013, Oonincx and Dierenfeld, 2011; Pennino et al., 1991). The carbohydrate content of yellow mealworm larvae can vary between one and seven percent (RamosElorduy et al., 2002). However, these differences are likely the result of the food remaining in the gastro-intestinal tract.

\section{Fibre and chitin}

Insects contain significant amounts of fibre as measured by crude fibre, acid detergent fibre, or neutral detergent fibre (Barker et al., 1998; Finke, 2002, 2007, 2013; Lease and Wolf, 2010; Madibela et al., 2007; Marono et al., 2015; Oonincx and Dierenfeld, 2011; Pennino et al., 1991). The components in these fibre fractions are not well known, although in whole insects they include sclerotised proteins and proteins, minerals and other compounds bound to chitin (Finke, 2007; Kramer et al., 1995; Madibela et al., 2007; Marono et al. 2015). Chitin is a $\mathrm{N}$-acetyl- $\beta$-D-glucosamine polymer, which provides rigidity to the insect's exoskeleton.

The outmost part of insects, the cuticle, is a matrix of proteins, lipids, minerals and other compounds (Kramer et al., 1995). Chitin is only present in the procuticle, the two innermost layers of the cuticle (Moussian, 2010), and therefore makes up a small part of an insect's weight. Quantitative data on the chitin content of whole insects is limited and comparisons between studies are difficult, due to the use of various analytical methods (Cauchie, 2002; Finke, 2007; Henriques et al., 2020; Kaspari, 1991; Lease and Wolf, 2010; Woods et al., 2020). Traditional fibre assays 
(crude, neutral detergent or acid detergent) are sometimes used to approximate chitin, even though these methods overestimate true chitin levels (Finke, 2007, 2013; Madibela et al., 2007; Marono et al., 2015). Many animal species, including humans, have chitinases, which can digest chitin (Fujimoto et al., 2002; Lindsay et al., 1984; Paoletti et al., 2007; Strobel et al., 2013; Tabata et al., 2018; Whitaker et $a l ., 2004)$. To what extent these enzymes are effective $i n$ vivo is currently unknown.

The predominant compound in the cuticle of most insects is not chitin, but protein (Kramer et al., 1995). 'Harder bodied' insects such as adult yellow mealworm beetles contain higher fibre levels than softer bodied insects such as silkworms and house cricket nymphs. This is due to higher levels of amino acids in the acid detergent fibre fraction (Finke, 2007). The amino acid pattern of whole insects differs from the pattern in the acid detergent fibre fraction, and differs between species (Finke, 2007). Particularly valine, histidine, and glycine concentrations are higher in the acid detergent fibre fraction than in whole insects. These amino acids likely contribute to the relative strength, stiffness, elasticity and other physical properties of sclerotised and cuticular proteins. Insects with 'harder' cuticles do not necessarily contain more chitin, but contain more sclerotised protein and proteins cross-linked to chitin than softer bodied insects. However, the chitin content of adult beetles does seem higher than in their larvae (Finke, 2007; Kaya et al., 2014; Shin et al., 2019).

\section{Minerals}

Minerals are classified as macro-minerals (calcium, phosphorus, magnesium, sodium, potassium and chloride) and micro or trace minerals (iron, zinc, copper, manganese, iodine and selenium). This classification is based on the amount needed to meet dietary requirements. For most species, requirements for macro-minerals are measured in $\mathrm{g}$ per $\mathrm{kg}$ and micro-mineral requirements in $\mathrm{mg}$ per $\mathrm{kg}$.

Insects generally contain low levels of calcium because they lack a mineralised skeleton. Calcium levels are typically less than $0.3 \%$ DM although higher levels have been reported for stoneflies (Plecoptera) and some other species (Barker et al., 1998; Finke, 2002, 2013; Oonincx and Dierenfeld, 2012; Oonincx and Van der Poel, 2011; Punzo, 2003; Studier and Sevick, 1992). Higher levels of calcium occasionally reported for feeder crickets are likely due to dietary calcium remaining in the gut (Barker et al., 1998; Finke, 2002; Frye and Calvert, 1989; Hatt et al., 2003; Oonincx and Dierenfeld, 2011; Oonincx and Van der Poel, 2011; Punzo, 2003). While the exoskeleton of most insects is primarily composed of protein and chitin, black solder fly larvae (Finke, 2013; Spranghers et al., 2017), and face fly larvae (Musca autumnalis) (Dashefsky et al., 1976; Koo et al., 1980; Roseland et al., 1985), have a mineralised exoskeleton in which calcium and other minerals are incorporated into the cuticle. Therefore, they can contain high levels of calcium.

Most insects contain more phosphorus than calcium, except for species with a mineralised exoskeleton (i.e. face fly and black soldier fly larvae). Significant amounts of phosphorus are present in plants as phytate and are hence unavailable for digestion. In contrast, phosphorus in insects is likely to be bioavailable as was reported when face fly pupa were fed to poultry (Dashefsky et al., 1976).

Magnesium levels in insects likely meet the dietary requirements of most species (Barker et al., 1998; Finke, 2002, 2013; Oonincx and Dierenfeld, 2012; Studier and Sevick, 1992). Black soldier fly larvae contain 3 to 10 times more magnesium than most other insects (Finke, 2013; Spranghers et al., 2017). This is likely the result of their mineralised exoskeleton in which minerals such as calcium and magnesium form a complex with chitin (Diener et al., 2015).

Only a few studies report the sodium and potassium content of insects (Finke, 2002, 2013; Oonincx and Dierenfeld, 2011; Oonincx and Van der Poel, 2011; Reichle et al., 1969; Studier and Sevick, 1992). Insects typically contain more potassium than sodium whereas chloride levels are intermediate. Most insect species likely contain adequate amounts of these three minerals to meet the dietary requirements of most animal species.

Most insects contain sufficiently high levels of the trace minerals iron, zinc, copper, manganese and selenium, which would meet the dietary requirements for most animals (Barker et al., 1998; Finke, 2002, 2013; Oonincx and Dierenfeld, 2012; Oonincx and Van der Poel, 2011; Punzo, 2003; Studier and Sevick, 1992). However, studies suggest possible species-specific differences for certain trace minerals. For example, the manganese concentrations in the alates of five termite species $(2,710-5,150 \mathrm{mg} / \mathrm{kg}$ DM) were extremely high compared to mopane worms (Gonimbrasia belina; $39 \mathrm{mg} / \mathrm{kg}$ DM), house crickets (38 mg/kg DM), yellow mealworms (5 mg/kg DM), or migratory locusts (10 $\mathrm{mg} / \mathrm{kg} \mathrm{DM})$ determined in the same study (Verspoor et al., 2020). However, other termite species from other regions, for instance Nasutitermes spp., from Venezuela, reportedly have lower manganese concentrations (32-115 mg/kg DM) (Oyarzun et al., 1996). Caste differences were apparent in the latter study; alates had a far lower manganese concentration than workers (37 vs 115 mg/kg DM).

Adult fruit flies (Drosophila melanogaster) (Barker et al., 1998; Oonincx and Dierenfeld, 2012), and house flies (Finke, 2013), contain relatively high levels of iron (125 to $454 \mathrm{mg} /$ $\mathrm{kg}$ DM) compared to most other insect species. Iron and zinc concentrations in insects seem positively correlated 
(Spearman's $\rho=0.592$ ), that is higher iron concentrations often coincide with higher zinc concentrations (Mwangi et al., 2018). The contents of the gastrointestinal tract can be a significant percentage of the total weight of an insect (4-7\% of the live weight) (Finke, 2003); and therefore diet also directly influences the (trace) mineral content of fully fed insects.

Mineral availability can be inhibited by so-called antinutritional factors such as phytate, oxalate, and tannins. For example, caterpillars of the Pallid emperor moth (Cirina forda) contain both phytic acid $(10 \mathrm{mg} / \mathrm{kg})$ and oxalate (40 mg/kg), but no tannins (Omotoso, 2006). Tannins $(10.4 \mathrm{mg} / \mathrm{kg})$, phytic acid $(13.5 \mathrm{mg} / \mathrm{kg})$ and oxalates $(0.8$ $\mathrm{mg} / \mathrm{kg}$ ) were found in larvae of the African palm weevil (Rhynchophorus phoenicis) (Ekpo, 2011). The source of these anti-nutritional factors is likely from the food present in the gastrointestinal tract. Evidence of accumulation of these substances in insects is lacking. The concentrations found seem to be relatively low; in seeds and cereal grains concentrations up to 7\% DM have been found (Zhou and Erdman, 1995).

\section{Vitamins and carotenoids}

\section{Vitamin A}

Vitamin A is a group of compounds composed of retinoids and carotenoids. Like most vertebrates, insects obtain retinoids via the cleavage of various carotenoids (Von Lintig, 2012). However, carotenoid cleavage in vertebrates primarily takes place in the intestine, and the resulting retinoids are stored in the liver (Olson, 1989), whereas insects convert carotenoids to retinoids only in the compound eye (Von Lintig, 2012). In fruit flies and honey bees (Apis mellifera) retinoids are only found in the compound eye while other parts of the adult insect do not contain retinoids nor do fruit fly larvae (Giovannucci and Stephenson, 1999; Goldsmith and Warner, 1964). This explains why holometabolous adults contain very low levels of vitamin A/retinoids (Barker et al., 1998; Finke, 2002, 2013; Oonincx and Dierenfeld, 2012; Oonincx and Van der Poel, 2011; Pennino et al., 1991), and holometabolous larvae, which lack compound eyes, do not contain preformed retinoids (retinal or 3-hydroxyretinal).

In many animal species certain carotenoids can be converted to vitamin A/retinal (Bender, 2002; Levi et al., 2012; McComb, 2010; Olson, 1989). High levels of carotenoids, including those that can be converted to retinal, are found in various wild insect species (Arnold et al., 2010; Cerda et al., 2001; Eeva et al., 2010; Isaksson and Andersson, 2007; Newbrey et al., 2013; Seki et al., 1998; Ssepuuya et al., 2017) whereas commercially produced insects contain far lower quantities (Finke, 2002, 2013, 2015a; Oonincx and Van der Poel, 2011). This difference is likely a result of dietary carotenoid intake as was shown for both silkworm larvae (Chieco et al., 2019) and fruit flies (Giovannucci and Stephenson, 1999).

\section{Vitamin D}

For a long time, insects were considered to contain low levels of vitamin D (typically <400 IU/kg DM) (Finke, 2002, 2013, Oonincx et al., 2010). However, data from three wild caught species indicated a high variability in its concentrations with values ranging from below the detection limit (100 IU vitamin D3/kg DM) up to 1,288 IU vitamin D3/kg DM (Finke, 2015b). More recently it was discovered that certain insects, like vertebrate animals, can synthesise vitamin D3 de novo when exposed to UV-B (Oonincx et al., 2018). This capacity varies greatly between species; no evidence of de novo synthesis is found in black soldier fly larvae, but yellow mealworm larvae can reach over 6,000 IU/kg DM (Oonincx et al., 2018).

\section{Vitamin E}

Vitamin E content of insects, including house crickets, yellow mealworm larvae and black soldier fly larvae, varies. Values for house crickets range from 8 to 195 IU vitamin $\mathrm{E} / \mathrm{kg}$ DM, yellow mealworm larvae range from $<22$ to 116 IU vitamin E/ kg DM and black soldier fly larvae range from 10 to 235 IU vitamin E/kg DM (Finke, 2002; Pennino et al., 1991). This variation is likely due to dietary differences resulting in different amounts being incorporated in the insect's tissues and dietary vitamin $\mathrm{E}$ in the insect's gastrointestinal tract. While variable between species, the vitamin $\mathrm{E}$ content of most commercially raised insects is below 37 IU/kg DM (Barker et al., 1998; Finke, 2002, 2013; Oonincx and Dierenfeld, 2011). Wild insects appear to contain higher levels of vitamin $\mathrm{E}$ than commercially raised insects, which are often provided with diets containing low levels of vitamin E (Pennino et al., 1991; Punzo, 2003).

\section{B-vitamins}

Several studies report on the B-vitamin content of commercially raised insects (Bawa et al., 2020; Finke, 2002, 2013, 2015b; Jones et al., 1972). However, the B-vitamin content of unprocessed wild-caught insects is limited (Finke, 2015b; Igwe et al., 2011; Kinyuru et al., 2010a,b). Some information on B-vitamin content of wild-caught insects consumed by humans is available (Banjo et al., 2006; Dreyer and Wehmeyer, 1982; Igwe et al., 2011; Kinyuru et al., 2010a; Kodondi et al., 1987; Santos Oliveira et al., 1976; Teffo et al., 2007). These, however, are usually dried, boiled, fried, or roasted and specific body parts are often removed. During this processing some B-vitamins can be destroyed by exposure to heat, light or oxygen. Furthermore, differences in sample preparation and analytical methods (microbiological versus chemical techniques) complicate direct comparisons. 
Despite these issues some general observation regarding B-vitamins in insects can be made. Most studies show unprocessed insects are a very good source of riboflavin (vitamin B2), niacin, pantothenic acid, pyridoxine (vitamin B6), biotin, folic acid, and cyanocobalamin (vitamin B12). Low levels for several of these vitamins occasionally reported in the literature are likely due to losses during processing and storage (Kinyuru et al., 2010a).

One B-vitamin that appears to be low in many species of insects is thiamine (vitamin B1). Many species of commercially raised or wild caught insects including house crickets, adult yellow mealworms, superworms (Zophobas morio), butterworms, (Chilecomadia moorei) Turkistan roaches (Blatta lateralis), pallid wing grasshoppers (Trimerotropis pallidipennis), and rhinoceros beetles (Oxygrylius ruginasus) contain low levels of thiamine (<3.0 mg/kg DM) although others (black soldier fly larvae, adult house flies, silkworms, yellow mealworm larvae, waxworms (Galleria mellonella), and white-lined sphinx moths (Hyles lineata) contain much higher levels (5.0 to $45.0 \mathrm{mg}$ thiamine/kg DM) (Bawa et al., 2020; Finke, 2002, $2013,2015 b)$. This variation is similar to that observed for 14 insect species collected in Nigeria (0.3 to $32.4 \mathrm{mg}$ thiamine/kg dry mater) (Banjo et al., 2006) and three species from Angola (1.3 to $36.7 \mathrm{mg}$ thiamine/kg DM) (Santos Oliveira et al., 1976). Dried and smoked Attacidae caterpillars (Nudaurelia melanops, Imbrasia truncata, Imbrasia epimethea) from Zaire contain low thiamine levels (1.5 to $2.7 \mathrm{mg} / \mathrm{kg}$ dry product) (Kodondi et al., 1987) and unprocessed longhorn grasshoppers from East Africa contained no detectable thiamine (Kinyuru et al., 2010b). Because thiamine is relatively unstable and most of the values reported are for insects processed (i.e. body parts removed and dried, smoked or fried), it is unclear how representative these values are for unprocessed insects. That said, the range of values for thiamine in processed insects is similar to that observed for raw insects.

Two species of edible insects (domesticated silkworm larvae and African silkworm pupae (Anaphe spp.) contain the enzyme thiaminase (Nishimune et al., 2000). Unless inactivated during processing, thiaminase destroys thiamine. Thiamine deficiency due to the consumption of Anaphe pupae is suggested as a cause of a seasonal ataxia in local populations in Nigeria (Adamolekun, 1993; Adamolekun et al., 1997). Most enzymes are inactivated by heat, but some thiaminase activity remains after brief exposure of the extract of Anaphe pupae to $100{ }^{\circ} \mathrm{C}$, suggesting it is heat tolerant. This thiaminase had an optimal activity at $70{ }^{\circ} \mathrm{C}$ and only after 15 minutes exposure to $100{ }^{\circ} \mathrm{C}$ was it largely deactivated (Nishimune et al., 2000). The gut of the variegated grasshopper (Zonocerus variegatus) also contains a thiaminase (Ehigie et al., 2013). This, however, has its optimal activity at a lower temperature $\left(50{ }^{\circ} \mathrm{C}\right)$ indicating it is a different enzyme. It is currently unknown how widespread thiaminases are in insects.

\section{Choline}

Choline is a component of both lecithin and the neurotransmitter acetylcholine. It also plays an important role in one-carbon metabolism and as such can spare the need for dietary methionine (Pesti et al., 1979). The data on choline in insects, albeit limited, indicate insects contain high levels of choline (1,570 to 7,258 mg/kg DM) (Finke, 2002, 2013, 2015a,b; Fogang et al., 2017; Noland and Baumann, 1949). Because methionine is typically the first-limiting amino acid when fed to most species, choline content is important when using insects as food or feed.

\section{Taurine}

Most animal species can synthesise taurine from its precursor methionine. For some species, such as cats and foxes, this amino sulfonic acid is a required nutrient. In general insect larvae contain little, if any, taurine (Bodnaryk, 1981; Finke, 2002, 2013, 2015a; Massie et al., 1989; Ramsey and Houston, 2003). Larvae of both the bertha armyworm (Mamestra configurata) and fruit flies contain little $(<200$ $\mu \mathrm{g} / \mathrm{g}$ fresh weight), or undetectable taurine but levels increase in pupae and peak in adults (Bodnaryk, 1981; Massie et al., 1989) with values ranging from 500 to 1,100 $\mu \mathrm{g} / \mathrm{g}$ fresh weight, likely because insect flight muscles contain high concentrations of taurine (Whitton et al., 1987). Adult house crickets (Finke, 2002, 2015a), adult pallid wing grasshoppers (Finke, 2015b), adult fruit flies (Massie et al., 1989), house flies (Finke, 2013), and adult moths (Bodnaryk, 1981; Finke, 2015b) are rich sources of taurine, while three species of adult beetles (T. molitor, $O$. ruginasus and an unreported species) contain only low levels (Finke, 2002, 2015b; Ramsey and Houston, 2003).

\section{Sterols}

Unlike most animals, insects cannot synthesise the characteristic ring structure of sterols and hence, require a dietary source (Jing and Behmer, 2020). The sterol form therefore depends on the diet and the insect species. Phytosterols such as stigmasterol, sitosterol, and campesterol, or zoosterols such as cholesterol and 7-dehydrocholesterol, are enzymatically converted for their required function. Typically they form structural components of phospholipid bilayers in cell membranes, but are also used as precursors for vitamin D or moulting hormone. Total sterol content and the variation seems a function of species, diet, life stage and season (Connor et al., 2006; Koštál et al., 2013; Liland et al., 2017). While insects contain a variety of sterols often $\beta$-sitosterol, cholesterol, or 7-dehydrocholesterol are the most abundant (Cerda et al., 2001; Cheseto et al. 2015; Connor et al., 2006; Jing and 
Behmer, 2020; Koštál et al., 2013; Liland et al., 2017; Mlček et al., 2019; Sabolová et al., 2016; Svoboda et al., 1995). High dietary levels of sterols, such as cholesterol, can increase the risk of atherosclerosis in humans and some species of monkeys (Hopkins, 1992; Rudel et al., 1998).

\section{Life stage effects on fat content}

Fat stores are usually highest in the final larval or nymphal stage (Fast, 1970). This pattern depends to some extent on whether the species is holometabolous or hemimetabolous. Larvae of holometabolous species have a higher fat content than adults (Lease and Wolf, 2011; Punzo, 2003). For instance, the fat content of the larvae of fruit flies (Church and Robertson 1966), house flies (Pearincott, 1960), black soldier flies (Liu et al., 2017) and yellow mealworms (Finkel, 1948) increases as they develop but drops significantly in the adult because fat is used as an energy source during pupation. A similar decrease is observed in insects undergoing diapause or hibernation (Ali and Ewiess, 1977; Downer and Matthews, 1976).

Similar to holometabolous insects, nymphs of hemimetabolous insects slowly increase their fat content as they develop as was shown for house crickets (Hutchins and Martin, 1968; Lipsitz and McFarlane, 1971). However, unlike holometaboulous insects, the fat contents of newly emerged hemimetabolous adults are similar to late stage nymphs and then slowly decline (Lipsitz and McFarlane, 1971).

\section{Dietary effects on insect nutrient composition}

Diet can affect the composition of fats/fatty acids, vitamins, carotenoids, and minerals in insects. The amount and the fatty acid composition of insect fat is highly variable and affected by both life stage and diet. This subsequently affects the levels of other nutrients, most notably protein and moisture. An increase in fat content, with stable amounts of moisture and protein, dilutes the concentrations of the latter two as was shown for house fly larvae (Pearincott, 1960).

\section{Fat}

The extent to which dietary changes in crude fat content and fatty composition of insects are possible depends strongly on the species. For instance, the fat content of yellow mealworms fed four different diets ranged from 23 to 29\% DM, while Argentinean cockroaches (Blaptica dubia) fed these diets ranged from 16 to $40 \%$ DM (Oonincx et al., 2015a). Similarly, the fat content of house crickets fed five different diets ranged from 9 to 44\% (Bawa et al., 2020). The fat content of velvet bean caterpillars (Anticarsia gennatalis) is 40 to $65 \%$ higher on an artificial diet compared to leaves from three plants (Cookman et al., 1984). This increase in fat content carried through to the adult stage; moths from larvae fed the artificial diet contained 71 to $105 \%$ more fat than those fed plant leaves (Cookman et al., 1984). Similarly, higher fat contents were found in dried insect meals from larvae of the tobacco hornworm ( 21 vs $17 \%$ dry DM) and the fall armyworm (Spodoptera frugiperda) (21 vs $12 \%$ DM) fed artificial diets, compared to those fed leaves or grasses (Landry et al., 1986).

Besides the variability in total fat content, large differences in fatty acid composition of insects when fed different diets are apparent, which is similar to most vertebrates. Numerous studies indicate that the fatty acid composition in both larval and adult insects partially reflects the fatty acid composition of the diet (Cookman et al., 1984; Madariaga et al., 1971; Schaefer, 1968; Spranghers et al., 2017; St-Hilaire et al., 2007; Van Broekhoven et al., 2015). However, due to selective accumulation, catabolism and/or fatty acid synthesis these fatty acid compositions are not identical (Cookman et al., 1984; Madariaga et al., 1971; Oonincx et al., 2015a; Schaefer, 1968).

The omega-3 fatty acid content of house fly larvae (Hussein et al., 2017), black soldier fly larvae (Erbland et al., 2020; Oonincx et al., 2019a; St-Hilaire et al., 2007), Jamaican field crickets (Komprda et al., 2013; Starčević et al., 2017), house crickets (Finke 2015b; Oonincx et al., 2019a), yellow mealworms (Fasel et al., 2017; Finke 2015b; Oonincx et al., 2019a), lesser mealworms (Oonincx et al., 2019a), superworms, and waxworms (Finke, 2015b; Komprda et al., 2013), are increased by providing a diet enriched with these fatty acids. Black soldier fly larvae fed diets containing fish oil or fish by-products accumulate both eicosapentaenoic acid and docosahexaenoic acid (Erbland et al., 2020; StHilaire et al., 2007). In contrast house crickets, superworms and waxworms fed diets containing fish oil accumulate eicosapentaenoic acid but not docosahexaenoic acid, even though both were present in the diets (Finke, 2015b). To which extent this is due to species, diet, or experimental setup requires further studies. When, and for how long these fatty acids should be provided will partially depend on the further use of the insect. Addition at the final developmental stage (i.e. gut-loading) might be suitable if whole insects, including the gastrointestinal contents, are used.

\section{Vitamins}

There are little data regarding the effect of diet on the vitamin content in insects. Supplementing the diets of house crickets, yellow mealworms, superworms, and waxworms with high levels of vitamin E during growth, resulted in high levels in the insects (116-440 IU/kg DM) (Finke, 2015a). Because the insects were fasted prior to analysis, these elevated levels are mainly due to incorporation of vitamin $\mathrm{E}$ into the tissue of the insect. This is similar to swine, where elevated levels of dietary vitamin E increase 
the vitamin $\mathrm{E}$ concentration of various tissues (Asghar et al., 1991). Carotenoid content can also be increased via the insect's diet. Feeding a diet containing $\beta$-carotene to species that use retinal as their chromophore such as house crickets, yellow mealworm larvae, and superworm larvae increases $\beta$-carotene concentration in their tissues (Finke, 2015a). Providing a diet containing $\beta$-carotene to species that use 3-hydroxyretinal as their chromophore such as Diptera and Lepidoptera typically does not increase $\beta$-carotene but elevates zeaxanthin levels as was shown for blow flies (Calliphora) (Vogt and Kirschfeld, 1984), fruit flies (Giovannucci and Stephenson, 1999), and waxworm larvae (Finke, 2015b). However, pupae from two silkworm strains did contain some $\beta$-carotene when the larvae were fed diets containing $\beta$-carotene (Chieco et al., 2019). Fruit fly larvae accumulate carotenoids and convert these to retinoids when they form compound eyes during pupation (Seki et al., 1998; Von Lintig, 2012).

\section{Minerals and heavy metals}

To some extent mineral composition can be altered by diet, depending on the mineral and the species of insect. Across three different studies the calcium content of black soldier fly prepupae fed nine different diets ranged from 1 to 66 g/kg DM (Proc et al., 2020; Spranghers et al., 2017; Wang et al., 2020). Iron, zinc, and manganese also varied while phosphorus and potassium were similar across dietary treatments. The mineral content of black soldier fly larvae fed sixteen different diets also varied greatly ( 8 to $83 \mathrm{~g} / \mathrm{kg}$ DM) although in this case part of the effects are likely a result of the diet remaining in the gastrointestinal tract of the larvae (Liland et al., 2017; Schmitt et al., 2019; Tschirner et al., 2015). The mineralised exoskeleton of black soldier fly larvae might be the reason for these extreme variations. Zinc also accumulates in black soldier fly larvae, prepupae and adults when incorporated in the larval diet (Diener et al., 2015). Zinc accumulates in larval and prepupal exuvia, further indicating that the variability in mineral concentrations is due to the mineralised exoskeleton of this species. In housefly pupae, reared on diet spiked with zinc chloride, the zinc concentration increased by approximately $10 \%$ of the dietary concentration, which might indicate effects from gut loading, rather than selective accumulation and storage (Maryanski et al., 2002). Like zinc, the heavy metals copper, cadmium and lead accumulate in black soldier fly larvae (Diener et al., 2015; Purschke et al., 2017; Van der Fels-Klerx et al., 2016; Wu et al., 2020). A measure for the efficiency of accumulation is the bio accumulation factor (BAF). It is calculated by dividing the concentration in the insect, by the concentration in the diet. Hence, a BAF above 1 indicates selective accumulation and a BAF below 1 indicates selective excretion. The aforementioned studies indicate that the BAF for arsenic, mercury, chrome, and nickel are below 1 in the black soldier fly. However, contrasting data has been reported by Schmitt et al. (2019) confirming accumulation of cadmium and mercury and selective excretion for lead and copper. The accumulation of cadmium seems to occur in several fly species, including houseflies, fruit flies, several midge species, and the flesh fly Boettcherisca peregrina (Charlton et al., 2015; Gao et al., 2017; Kazimírová and Ortel, 2000; Maroni and Watson, 1985; Maryanski et al., 2002; Postma et al., 1996; Purschke et al., 2017; Timmermans and Walker, 1989; Wu et al., 2006).

In contrast to these Diptera, larvae of the yellow mealworm larvae accumulate arsenic, but not copper, zinc, lead or cadmium (Van der Fels-Klerx et al., 2016; Vijver et al., 2003). The concentrations of lead and cadmium in this species can, however, increase partially due to the presence of these elements in the gastro-intestinal tract (Vijver et al., 2003). This was for instance shown for the predatory beetle (Notiophilus biguttatus), which efficiently excreted retained cadmium when it was removed from the diet (Jansen et al., 1991). Similarly, the predatory carabid beetle (Poecilus cupreus) had increased cadmium levels (approximately 10\% of the dietary concentration), and zinc (less than $10 \%$ of the dietary concentration) when provided with spiked diets (Maryanski et al., 2002). However, when provided with a cadmium free diet, concentrations fell rapidly (Kramarz, 1999). The cadmium concentration in the sago grub was below $10 \%$ of the dietary concentration (Köhler et al., 2020) and no evidence of cadmium or zinc accumulation was found in the beetle Neochetina eichhorniae (Jamil and Hussain, 1992).

Several studies on heavy metals in Orthopterans, either taken from contaminated sites or experimentally exposed, have been conducted. Higher levels in the environment lead to higher levels of lead, cadmium, and mercury in four species of grasshoppers (Devkota and Schmidt, 2000). The BAF for cadmium was above 1 , whereas it was below 1 for lead. Interestingly, the BAF for mercury was below 1 for three of the species, but $>2$ for the fourth. A higher BAF for cadmium than for lead was also reported for the Oriental longheaded grasshopper (Acrida chinensis) and migratory locusts (Zhang et al., 2012). Both cadmium and copper concentrations increased in migratory locusts with increased dietary levels (Crawford et al., 1996). The same was also found in the common field grasshopper (Chorthippus brunneus), and it was shown that most of the cadmium and copper (85\% for both) accumulated in the integument (Hunter et al., 1987). This might explain why lower concentrations are often found in later instar nymphs and adults which have a lower surface to volume ratio.

Jamaican field crickets (Gryllus assimilis) also accumulate dietary cadmium (Bednarska et al., 2015). However, their zinc levels remain constant at different dietary levels indicating that zinc concentrations are more tightly regulated. Tight regulation of heavy metals that are of 
nutritional relevance, such as iron, zinc, and copper, seems common over a variety of insect species. This is plausible, as a variety of selective transporters are present to regulate their concentrations within the insect (Mwangi et al., 2018).

Tobacco cutworms (Spodoptera litura) also concentrate copper and zinc from their diet in amounts that seem to fit physiological levels (7 and $70 \mathrm{mg} / \mathrm{kg}$ fresh weight, respectively) (Zhuang et al., 2009). Lead, and especially cadmium, are largely excreted by this lepidopteran. A noteworthy ecological study on the Bogong moth (Agrotis infusa) indicates that they store arsenic and can effectively transport this pollutant during migration (Green, 2008).

Based on the information above, it seems that accumulation and excretion patterns show similarities at the order level. However, these patterns differ between life stages (Lindqvist, 1992; Timmermans and Walker, 1989), and species-specific exceptions likely exist. Therefore, if a new species is to be commercially produced, controlled studies on accumulation and excretion patterns are advisable. Variation in dietary intake levels will to some extent affect insect concentrations. For species collected from the field, seasonal differences in host plants and host plant concentrations will affect insect concentrations (Ortiz et al., 2015; Zhang et al., 2009). Furthermore, insects from contaminated areas can have elevated concentrations due to contaminated diets, but might also take up these minerals directly from the environment.

\section{Environmental effects on insect composition}

Environmental factors such as temperature, light, and humidity are known to affect growth and development (Akman Gündüz and Gülel 2002; Ali and Ewiess, 1977; Ali et al., 2011; Han et al., 2008; Roe et al., 1980, 1985). Some effects on chemical composition are also known to occur. For instance, bean beetles (Acanthoscelides obtectus) raised at $30^{\circ} \mathrm{C}$ contain more protein and the same amount of fat as their counterparts raised at $20^{\circ} \mathrm{C}$ (Sönmez and Gülel, 2008). An increase in rearing temperature from 20 to $27^{\circ} \mathrm{C}$ in two-spotted field crickets (Gryllus bimaculatus) decreases their protein concentration and increases the concentration of fat (Hoffmann, 1973). Their fatty acid profile also changes with higher temperatures leading to a higher degree of saturation. This coincides with an increased fresh weight per individual, possibly indicating an increased synthesis of saturated fatty acids at $27^{\circ} \mathrm{C}$. Similarly, females of the mosquito, Culex tarsalis, contain more unsaturated fatty acids (C16:1, C18:1 and C18:2) when raised at $22^{\circ} \mathrm{C}$, compared to counterparts raised at $30^{\circ} \mathrm{C}$ which contain more short chain fatty acids (Harwood and Takata, 1965). This accumulation of unsaturated fatty acids is more pronounced when this species is raised under a short photoperiod, which would increase cold survival. Indeed, photoperiodic effects on insect nutrient content are likely indirect, acting through other processes such as preparing for diapause.

Besides photoperiod, the emission spectrum of the light source can influence composition. If UV-B is emitted, this will lead to vitamin D3 synthesis in certain insects such as the yellow mealworm (Oonincx et al., 2018). The vitamin D3 concentration increases over time with prolonged exposure until it reaches a plateau. A higher plateau is reached with a higher UV-B intensity. A higher abundance of short wavelengths within the UV-B spectrum is also likely to lead to a higher vitamin D3 content in insects, as was shown in the vertebrate Pogona vitticeps (Diehl et al., 2018).

\section{Processing effects on insect nutrient composition}

Although specific information on the effects of various processing methods on the nutrient content and availability of insect products is limited, it is likely similar to other human foods or animal feeds (Ssepuuya et al., 2017). Heat and processing effects on protein/amino acid availability, effects of traditional cooking methods on trace mineral, fatty acid and fat content and processing effects on B-vitamins in insect and insect products have been reported.

Processing using high pressures and temperatures decreases amino acid availability and protein quality (Batterham et al., 1986). As such, the protein quality of insect meals is likely decreased by processing conditions, especially drying temperatures. The lower average amino acid availability of house fly larvae meal (91\%), compared to house fly pupae meal (95\%), might partially be due to longer drying times (Pieterse and Pretorius, 2014). Likewise, dried Mopane caterpillars exposed to high temperatures during canning have a slightly reduced apparent protein digestibility compared to those that are not canned (83.9 and $85.8 \%$, respectively) (Dreyer and Wehmeyer, 1982). In contrast, no effect of processing (either boiling or frying) on protein digestibility or biological value was seen for four species of insects when fed to rats (Ekpo, 2011). Similarly, Jensen et al. (2019) report that neither protein digestibility, nor the biological value of lesser mealworm larvae is altered by freeze drying, vacuum drying at low $\left(40{ }^{\circ} \mathrm{C}\right)$, or higher (120-160 ${ }^{\circ} \mathrm{C}$ ) temperatures, industrial drying, defatting, extrusion, or by adding a blend of enzymes to the diet when fed to rats.

In addition to processing insects into meals for animal feed, protein extraction from raw insects for use in human food has also been evaluated (Lin et al., 1983; Ozimek et al., 1985, Yi et al., 2013). Dried and ground silkworm chrysalid protein was compared to an aqueous extract of ground silkworm chrysalid protein with and without pretreatment with hydrogen peroxide (Lin et al., 1983). Amino acid patterns were similar for the three treatments; 
however, sodium hydroxide treatment prior to extraction decreased cysteine levels. Whereas protein digestibility was similar between treatments, net protein utilisation was lower for the protein extract pre-treated with sodium hydroxide, probably due to cysteine destruction.

While some processing methods negatively affect protein/ amino acid availability, some can improve protein quality. Ozimek et al. (1985) evaluated the effect on amino acid pattern and availability and the net protein value of an alkaline extraction of dried adult honeybees fed to rats. This extraction increased protein quality of the concentrate compared to dried honeybees by elevating the relative abundance (amino acid/protein) of leucine (54\%) and methionine (59\%). Amino acid availability was also improved by extraction (90\%), compared to dried honeybees (65.4\%), and was similar to casein (92.2\%). The improved amino acid availability may partially be due to the removal of cuticular proteins complexed with chitin; the alkaline extraction decreased chitin content from $11.1 \%$ DM to below the detection limit. The improved amino acid profile and increased amino acid availability in the extract improved net protein utilisation from 41.5 to $60.6 \%$ compared to dried adult honeybees.

The nutrient content of insects prepared for human consumption may be altered by traditional cooking methods in two ways. Depending on the type of cookware used, iron, zinc, copper, and nickel can leach from the cookware and into the insect during preparation. The high values for copper, iron and zinc reported for some insects prepared using traditional methods may be partially due to the cookware used (Payne et al., 2015; Santos Oliveira et al., 1976). Additionally, many insects consumed by humans are either broiled, roasted, or fried prior to consumption. Broiled or roasted insects contain less fat than raw insects as fat is lost during cooking. A comparison of traditional processing methods using four insect species (black soldier fly prepupae, house crickets, longhorn grasshoppers and the Egyptian cotton leafworm (Spodoptera littoralis)) showed decreases in fat content (0.8-51\%) and consequently increases of the crude protein (1.2-22\%) content (Nyangena et al., 2020). Fat content was the highest in the raw product and decreased in the following order: toasting, boiling, oven drying and solar-drying.

For fried insects, the fat content increases as the fat from the cooking oil is absorbed by the insect (Santos Oliveira et al., 1976). This also changes the fatty acid profiles, because this material contains both the fat naturally present in the insect and the fat in the cooking oil (Santos Oliveira et al., 1976).

As previously mentioned, some B-vitamins are relatively unstable when exposed to heat, light, or oxygen. The vitamin content of insects processed for human consumption is lower than raw unprocessed insects, possibly due to losses during cooking and drying. Kinyuru et al., (2010a) evaluated the effect of toasting (frying at approximately $150{ }^{\circ} \mathrm{C}$ for 5 minutes) and drying (solar drying at $30{ }^{\circ} \mathrm{C}$ ) on the niacin, riboflavin, pyridoxine, and folic acid content of Mendi termites and longhorn grasshoppers. Toasting decreased the folic acid content of these species by 37 and $43 \%$, respectively, and riboflavin by 23 and $34 \%$, respectively. In contrast there was little loss of pyridoxine and niacin. Drying of termites and grasshoppers also decreased both folic acid by 47 to $66 \%$, and riboflavin by 29 to $46 \%$. There was little loss of pyridoxine during drying and a significant loss of niacin for termites (26\%), but not for grasshoppers. The reason for these differences is unclear. Of note is that thiamine (vitamin B1) which is known to be unstable during heating was not measured in this study.

Dreyer and Wehmeyer (1982) showed that canning reduces thiamine (84\%), riboflavin (20\%) and niacin (42\%) levels in milled Mopane caterpillars, most likely because of the heat used to sterilise the cans. In contrast to the loss of $\mathrm{B}$-vitamins, $\beta$-carotene was unaffected by the canning process.

\section{Conclusions}

Insects have a high protein content and their amino acid profiles are suitable for production animals and humans alike. This protein is highly digestible; hence, insects are generally a good source of dietary protein. In most cases methionine is the first limiting amino acid when insects are used as food or feed. Fat is the next most prominent nutrient in insects. Large variations in fat content and fatty acid composition occur due to species, life stage, diet and gender.

Carbohydrates are virtually absent in the insect body but fibre is present in significant amounts. This fibre consists primarily of chitin and sclerotised proteins, which are components of the insect exoskeleton. Whereas calcium levels in insects are lower than in animals with an endoskeleton, most other minerals are present in adequate concentrations to meet nutrient requirements of animals and humans. Mineral concentrations can be especially high in certain fly larvae. Vitamin A levels in insects are low, however carotenoids can be present in relatively high concentrations, depending on the diet. Vitamin D content is highly variable and largely depends on the availability of UV-B radiation during insect development. Also vitamin E concentrations are highly variable and depend on dietary levels. Most B-vitamins are present in adequate concentrations in most insect species. The taurine content of insects is highly variable and depends on both species and life stage.

Several factors such as species and life stage influence the composition of insect species. Diet can strongly affect the 
concentration of most nutrients, although some, especially amino acids and minerals of nutritional relevance, tend to be less flexible. Heavy metals can accumulate in insects. However, accumulation patterns vary between species and orders. Insect processing can affect their nutritional value in many ways, but the most common are destruction of vitamins and denaturation of proteins due to heat. Although large variations in insect composition are known, in general they are to be considered a prime source of nutrients.

\section{Conflict of interest}

The authors declare no conflict of interest.

\section{References}

Adamolekun, B., 1993. Anaphe venata entomophagy and seasonal ataxic syndrome in southwest Nigeria. Lancet 341: 629.

Adamolekun, B., McCandless, D.W. and Butterworth, R.F., 1997. Epidemic of seasonal ataxia in Nigeria following ingestion of the African silkworm Anaphe venata: role of thiamine deficiency? Metabolic Brain Disease 12: 251-258.

Akman Gündüz, N.E. and Gülel, A., 2002. Effect of temperature on development, sexual maturation time, food consumption and body weight of Schistocerca gregaria Forsk. (Orthoptera: Acrididae). Türk Zooloji Dergisi 26: 223-227.

Ali, M. and Ewiess, M.A., 1977. Photoperiodic and temperature effects on rate of development and diapause in the green stink bug, Nezara viridula L. (Heteroptera: Pentatomidae). Zeitschrift Fur Angewandte Entomologie 84: 256-264.

Ali, M.F., Mashaly, A.M.A., Mohammed, A.A. and El-Magd Mahmoud Mohammed A., 2011. Effect of temperature and humidity on the biology of Attagenus fasciatus (Thunberg) (Coleoptera: Dermestidae). Journal of Stored Product Research 47: 25-31. https:// doi.org/10.1016/j.jspr.2010.07.002

Arnold, K.E., Ramsay, S.L., Henderson, L. and Larcombe, S., 2010. Seasonal variation in diet quality: antioxidants, invertebrates and blue tits Cyanistes caeruleus. Biological Journal of the Linnean Society 99: 708-717.

Asghar, A., Gray, J.I., Miller, E.R., Ku, P.K., Booren, A.M. and Buckley, D.J., 1991. Influence of supranutritional vitamin E supplementation in the feed on swine growth performance and deposition in different tissues. Journal of the Science of Food and Agriculture 57: 19-29.

Azzollini, D., Derossi, A., Fogliano, V., Lakemond, C.M.M. and Severini, C., 2018. Effects of formulation and process conditions on microstructure, texture and digestibility of extruded insectriched snacks. Innovative Food Science and Emerging Technologies 45: 344-353.

Bamgbose, A.M., 1999. Utilization of maggot-meal in cockerel diets. Indian Journal of Animal Sciences 69: 1056-1058.

Banjo, A.D., Lawal, O.A. and Songonuga, E.A., 2006. The nutritional value of fourteen species of edible insects in southwestern Nigeria. African Journal of Biotechnology 5: 298-301.

Barker, D., Fitzpatrick, M.P. and Dierenfeld, E.S., 1998. Nutrient composition of selected whole invertebrates. Zoo Biology 17: 123-134.
Batterham, E.S., Darnell, R.E., Herbert, L.S. and Major, E.J., 1986. Effect of pressure and temperature on the availability of lysine in meat and bone meal as determined by slope-ratio assays with growing pigs, rats and chicks and by chemical techniques. British Journal of Nutrition 55: 441-453.

Bawa, M., Songsempong, S., Kaewtapee, C. and Chanput, W., 2020. Effect of diet on the growth performance, feed conversion, and nutrient content of the house cricket. Journal of Insect Science 20: 1-10.

Bednarska, A.J., Opyd, M.O., Zurawicz, E. and Laskowski, R., 2015. Regulation of body metal concentrations: Toxicokinetics of cadmium and zinc in crickets. Ecotoxicology and Environmental Safety 119: 9-14.

Beenakkers, M.T.A., Van der Horst, D.J. and Van Marrewijk, W.J.A., 1985. Insect lipids and lipoproteins, and their role in physiological processes. Progress in Lipid Research 24: 19-67.

Bender, D.A., 2002. Introduction to nutrition and metabolism. CRC Press, London, UK, 450 pp.

Bodnaryk, R.P., 1981. The biosynthesis function, and fate of taurine during the metamorphosis of the Noctuid moth Mamestra configurata Wlk. Insect Biochemistry 11: 199-205.

Borgeson, C.E. and Blomquist, G.J., 1993. Subcellular location of the $\Delta^{12}$ desaturase rules out bacteriocyte contribution to linoleate biosynthesis in the house cricket and the American cockroach. Insect Biochemistry and Molecular Biology 23: 297-302.

Borgeson, C.E., Kurtti, T.J., Munderloh, U.G. and Blomquist, G.J., 1991. Insect tissues, not microorganisms, produce linoleic-acid in the house cricket and the American cockroach. Experientia 47: 238-241.

Bosch, G., Vervoort, J.J.M and Hendriks, W.H., 2016. In vitro digestibility and fermentability of selected insects for dog foods. Animal Feed Science and Technology 221: 174-184.

Bosch, G., Zhang, S., Oonincx, D.G.A.B. and Hendriks, W.H., 2014. Protein quality of insects as potential ingredients for dog and cat foods. Journal of Nutritional Science 3: e29.

Bukkens, S.G.F., 1997. The nutritional value of edible insects. Ecology of Food and Nutrition 36: 287-319.

Calvert, C.C., Martin, R.D. and Morgan, N.O., 1969. House fly pupae as food for poultry. Journal of Economic Entomology 62: 938-939.

Cauchie, H.M., 2002. Chitin production by arthropods in the hydrosphere. Hydrobiologia 470: 63-96.

Cerda, H., Martinez, R., Briceno, N., Pizzoferrato, L., Manzi, P., Tommaseo Ponzetta, M., Marin, O. and Paoletti, M.G., 2001. Palm worm: (Rhynchophorus palmarum) traditional food in Amazonas, Venezuela - nutritional composition, small scale production and tourist palatability. Ecology of Food and Nutrition 40: 13-32.

Charlton, A., Dickinson, M., Wakefield, M., Fitches, E., Kenis, M., Han, R., Zhu, F., Kone, N., Grant, M. and Devic, E., 2015. Exploring the chemical safety of fly larvae as a source of protein for animal feed. Journal of Insects as Food and Feed 1: 7-16. https://doi.org/10.3920/ JIFF2014.0020

Cheseto, X., Kuate, S.P., Tchouassi, D.P., Ndung'u, M., Teal, P.E. and Torto, B., 2015. Potential of the desert locust Schistocerca gregaria (Orthoptera: Acrididae) as an unconventional source of dietary and therapeutic sterols. PLoS ONE 10: e0127171. 
Chieco, C., Morrone, L., Bertazza, G., Cappellozza, S., Saviane, A., Gai, F., Di Virgilio, N. and Rossi, F., 2019. The effect of strain and rearing medium on the chemical composition, fatty acid profile and carotenoid content in silkworm (Bombyx mori) pupae. Animals 9: 103.

Church, R.B. and Robertson, F.W., 1966. A biochemical study of the growth of Drosophila melanogaster. Journal of Experimental Zoology 162: 337-351.

Connor, W.E., Wang, Y., Green, M. and Lin, D.S., 2006. Effects of diet and metamorphosis upon the sterol composition of the butterfly Morpho peleides. Journal of Lipid Research 47: 1444-1448.

Cookman, J.E., Angelo, M.J., Slansky Jr, F. and Nation, J.L., 1984. Lipid content and fatty acid composition of larvae and adults of the velvetbean caterpillar, Anticarsia gemmatalis, as affected by larval diet. Journal of Insect Physiology 30: 523-527.

Crawford, L.A., Lepp, N.W. and Hodkinson, I.D., 1996. Accumulation and egestion of dietary copper and cadmium by the grasshopper Locusta migratoria R and F (Orthoptera: Acrididae). Environmental Pollution 92: 241-246. https://doi.org/10.1016/0269-7491(96)000048

Dashefsky, H.S., Anderson, D.L., Tobin, E.N. and Peters, T.M., 1976. Face fly pupae: a potential feed supplement for poultry. Environmental Entomology 5: 680-682.

DeMarco, M., Martinez, S., Hernandez, F., Madrid, J., Gai, F., Rotolo, L., Belforti, M., Bergero, D., Katz, H., Dabbou, S., Kovitvadhi, A., Zoccarato, I., Gasco, L. and Schiavone, A., 2015. Nutritional value of two insect larval meals (Tenebrio molitor and Hermetia illucens) for broiler chickens: apparent nutrient digestibility, apparent ileal amino acid digestibility and apparent metabolizable energy. Animal Feed Science and Technology 209: 211-218.

Devkota, B. and Schmidt, G.H., 2000. Accumulation of heavy metals in food plants and grasshoppers from the Taigetos Mountains, Greece. Agriculture, Ecosystems and Environment 78: 85-91.

Diehl, J.J.E, Baines, F.M., Heijboer, A.C., Van Leeuwen, J.P., Kik, M., Hendriks, WH. and Oonincx, D.G.A.B., 2018. A comparison of UV b compact lamps in enabling cutaneous vitamin D synthesis in growing bearded dragons. Journal of Animal Physiology and Animal Nutrition 102: 308-316.

Diener, S., Zurbrugg, C. and Tockner, K., 2015. Bioaccumulation of heavy metals in the black soldier fly, Hermetia illucens and effects on its life cycle. Journal of insects and Food and Feed 1: 261-270. https://doi.org/10.3920/JIFF2015.0030

Downer, R.G.H. and Matthews, J.R., 1976. Patterns of lipid distribution and utilisation in insects. American Zoologist 16: 733-745.

Dreassi, E., Cito, A., Zanfini, A., Materozzi, L., Botta, M. and Francardi, V., 2017. Dietary fatty acids influence the growth and fatty acid composition of the yellow mealworm Tenebrio molitor (Coleoptera: Tenebrionidae). Lipids 52: 285-294.

Dreyer, J.J. and Wehmeyer, A.S., 1982. On the nutritive value of mopanie worms. South African Journal of Science 78: 33-35.

Eeva, T., Helle, S. and Salminen, J.P., 2010. Carotenoid composition of invertebrates consumed by two insectivorous bird species. Journal Chemical Ecology 36: 608-613.

Ehigie, L.O., Emuebie, O. and Ehigie, F.A., 2013. Biochemical properties of thiaminase, a toxic enzyme in the gut of grasshoppers (Zonocerus variegatus Linn). Cameroon Journal of Experimental Biology 9: 9-16.
Ekpo, K.E. 2011. Effect of processing on the protein quality of four popular insects consumed in Southern Nigeria. Archives of Applied Science Research 3: 307-326.

Erbland, P., Alyokhin, A., Perkins, L.B. and Peterson, M., 2020. Dosedependent retention of omega-3 fatty acids by black soldier fly larvae (Diptera: Stratiomyidae). Journal of Economic Entomology 113: 1221-1226. https://doi.org/10.1093/jee/toaa045

Fasel, N.J., Mène-Safrané, L., Ruczynski, I., Komar, E. and Christe, P. 2017. Diet induced modifications of fatty acid composition in mealworm larvae (Tenebrio molitor). Journal of Food Research 6: 5. https://doi.org/10.5539/jfr.v6n5p22

Fast, P.G., 1970. Insect lipids. Progress in the Chemistry of Fats and other Lipids 11: 181-242.

Finke M.D., 2002. Complete nutrient composition of commercially raised invertebrates used as food for insectivores. Zoo Biology 21: 269-285

Finke, M.D., 2003. Gut loading to enhance the nutrient content of insects as food for reptiles: a mathematical approach. Zoo Biology 22: 147-162.

Finke, M.D. 2004. The nutrient content of insects. In: Capinara, J.L. (ed.) Encyclopedia of entomology. Vol 2. Kluwer Academic Publishers, Dordrecht, the Netherlands, p. 1562-1575.

Finke, M.D., 2007. Estimate of chitin in raw whole insects. Zoo Biology 26: 105-115.

Finke, M.D., 2013. Complete nutrient content of four species of feeder insects. Zoo Biology 32: 27-36.

Finke, M.D., 2015a. Complete nutrient content of three species of wild caught insects, pallid-winged grasshopper, rhinoceros beetles and white-lined sphinx moth. Journal of Insects as Food and Feed 1: 281-292. https://doi.org/10.3920/JIFF2015.0033

Finke, M.D., 2015b. Complete nutrient content of four species of commercially available feeder insects fed enhanced diets during growth. Zoo Biology 34: 554-564.

Finke, M.D. and Oonincx, D.G.A.B., 2017. Nutrient content of insects. In: Van Huis, A. and Tomberlin, J.K. (eds) Insects as food and feed: from production to consumption. Wageningen Academic Publishers, Wageningen, the Netherlands, pp. 290-317.

Finke, M.D., DeFoliart, G.R. and Benevenga, N.J., 1987. Use of a fourparameter logistic model to evaluate the protein quality of mixtures of Mormon cricket meal and corn gluten meal in rats. Journal of Nutrition 117: 1740-1750.

Finke, M.D., Sunde, M.L. and DeFoliart, G.R., 1985. An evaluation of the protein quality of Mormon crickets (Anabrus simplex Haldeman) when used as a high protein feedstuff for poultry. Poultry Science 64: 708-712

Finkel, A.J., 1948. The lipid composition of Tenebrio molitor larvae. Physiological Zoology 21: 111-133.

Fogang, A.R., Kansci, G., Viau, M., Hafnaoui, N., Meynier, A., Demmano, G. and Genot, C., 2017. Lipid and amino acids profiles support the potential of Rhynchophorus phoenicis larvae for human nutrition. Journal of Food Composition and Analysis 60: 64-73.

Fontaneto, D., Tommaseo-Ponzetta, M., Galli, C., Risé, P., Glew, R.H. and Paoletti, M.G., 2011. Differences in fatty acid composition between aquatic and terrestrial insects used as food in human nutrition. Ecology of Food and Nutrition 50: 351-367. 
Frye, F.L. and Calvert, C.C., 1989. Preliminary information on the nutritional content of mulberry silk moth (Bombyx mori) larvae. Journal of Zoo and Wildlife Medicine 20: 73-75.

Fujimoto, W., Suzuki, M., Kimura, K. and Iwanaga, T., 2002. Cellular expression of the gut chitinase in the stomach of frogs Xenopus laevis and Rana catesbeiana. Biomedical Research-Tokyo 23: 91-99.

Gao, Q., Wang, X., Wang, W., Lei, C. and Zhu, F., 2017. Influences of chromium and cadmium on the development of black soldier fly larvae. Environmental Science and Pollution Research 24: 8637-8644.

Gasco, L., Biasato, I., Dabbou, S., Schiavone, A. and Gai, F., 2019. Animals fed insect-based diets: State-of-the-art on digestibility, performance and product quality. Animals 9: 170. https://doi. org/10.3390/ani9040170

Ghioni, C., Bell, J.G. and Sargent, J.R., 1996. Polyunsaturated fatty acids in neutral lipids and phospholipids of some freshwater insects. Comparative Biochemistry and Physiology B 114: 161-170.

Giovannucci, D.R. and Stephenson, R.S., 1999. Identification and distribution of dietary precursors of the Drosophila visual pigment chromophore: analysis of carotenoids in wild type and ninaD mutants by HPLC. Vision Research 39: 219-229.

Gladyshev, M.I., Kharitonov, A.Y., Popova, O.N., Sushchik, N.N., Makhutova, O.N. and Kalacheva, G.S., 2011. Quantitative estimation of dragonfly role in transfer of essential polyunsaturated fatty acids from aquatic to terrestrial ecosystems. Doklady Biochemistry and Biophysics 438: 141-143.

Goldsmith, T.H. and Warner, L.T., 1964. Vitamin A in the vision of insects. Journal of General Physiology 47: 433-441.

Goulet, G., Mullier, P., Sinave, P. and Brisson, G.J., 1978. Nutritional evaluation of dried Tenebrio molitor larvae in the rat. Nutrition Reports International 18: 11-15.

Green, K., 2008. Migratory bogong moths (Agrotis infusa) transport arsenic and concentrate it to lethal effect by estivating gregariously in alpine regions of the Snowy Mountains of Australia. Arctic, Antarctic, and Alpine Research 40: 74-80.

Hale, O.M., 1973. Dried Hermetia illucens (Stratiomyidae) as a feed additive for poultry. Journal of the Georgia Entomological Society 8: $16-20$.

Hall, H.N., Masey O’Neill H.V., Scholey D., Burton E., Dickinson M. and Fitches E.C. 2018. Amino acid digestibility of larval meal (Musca domestica) for broiler chickens. Poultry Science 97: 1290-1297.

Han, R.D., Parajulee, M., Zhong, H. and Feng, G., 2008. Effects of environmental humidity on the survival and development of pine caterpillars, Dendrolimus tabulaeformis (Lepidoptera: Lasiocampidae). Insect Science 15: 147-152.

Hanson, B.J., Cummins, K.W., Cargill, A.S. and Lowry, R.R., 1985. Lipid content, fatty acid composition, and the effect of diet on fats of aquatic insects. Comparative Biochemistry and Physiology B 80: 257-276.

Harwood, R.F. and Takata, N., 1965. Effect of photoperiod and temperature on fatty acid composition of the mosquito Culex tarsalis. Journal of Insect Physiology 11: 711-716

Hatt, J.M., Hung, E. and Wanner, M., 2003. The influence of diet on the body composition of the house cricket (Acheta domesticus) and consequences for their use in zoo animal nutrition. Der Zoologische Garten 73: 238-244.
Henriques, B.S., Garcia, E.S., Azambuja, P. and Genta, F.A., 2020. Determination of chitin content in insects: an alternative method based on calcofluor staining. Frontiers in Physiology 11: 117. https:// doi.org/10.3389/fphys.2020.00117

Henry, M., Gascob, L., Piccoloc, G. and Fountoulakia, E., 2015. Review on the use of insects in the diet of farmed fish: past and future. Animal Feed Science and Technology 203: 1-22.

Hoffmann, K.H., 1973. Effects of temperature on chemical composition of crickets (Gryllus, orthopt.) (In German). Oecologia 13: 147-175.

Hopkins, P.N. 1992. Effects of dietary cholesterol on serum cholesterol: a meta-analysis and review. American Journal of Clinical Nutrition 55: 1060-1070.

Hunter, B.A., Hunter, L.M., Johnson, M.S. and Thompson, D.J., 1987. Dynamics of metal accumulation in the grasshopper Chorthippus brunneus in contaminated grasslands. Archives of Environmental Contamination and Toxicology 16: 711-716.

Hussein, M., Pillai, V.V., Goddard, J.M., Park, H.G., Kothapalli, K.S., Ross, D.A., Ketterings, Q.M., Brenna, J.T., Milstein, M.B., Marquis, H., Johnson, P.A., Nyrop, J.P. and Selvaraj, V., 2017. Sustainable production of housefly (Musca domestica) larvae as a protein-rich feed ingredient by utilizing cattle manure. PLoS ONE 12: e0171708.

Hutchins, R.F.N. and Martin, M.M., 1968. The lipids of the common house cricket, Acheta domesticus L. I. Lipid classes and fatty acid distribution. Lipids 3: 247-249.

Hwangbo, J., Hong, E.C., Jang, A., Kang, H.K., Oh, J.S., Kim, B.W. and Park, B.S., 2009. Utilization of house fly-maggots, a feed supplement in the production of broiler chickens. Journal of Environmental Biology 30: 609-614.

Igwe, C.U., Ujowundu, C.O., Nwaogu, L.A. and Okwu, G.N., 2011. Chemical analysis of an edible African termite, Macrotermes nigeriensis, a potential antidote to food security problem. Biochemistry and Analytical Biochemistry 1: 1-4.

Iñiguez-Covarrubias, G., De Franco-Gömez, M.J. and Del R AndradeMaldonado, G., 1994. Biodegradation of swine waste by house-fly larvae and evaluation of their protein quality in rats. Journal of Applied Animal Research 5: 65-74.

Isaksson, C. and Andersson, S., 2007. Carotenoid diet and nestling provisioning in urban and rural great tits Parus major. Journal of Avian Biology 38: 564-572.

Jamil, K. and Hussain, S., 1992. Biotransfer of metals to the insect Neochetina eichhornae via aquatic plants. Archives of Environmental Contamination and Toxicology 22: 459-463.

Janssen, M., Bruins, A., De Vries, T. and Van Straalen, N., 1991. Comparison of cadmium kinetics in four soil arthropod species. Archives of Environmental Contamination and Toxicology 20: 305-312.

Janssen, R.H., Vincken, J.P., Van den Broek, L.A.M., Fogliano, V. and Lakemond, C.M.M., 2017. Nitrogen-to-protein conversion factors for three edible insects: Tenebrio molitor, Alphitobius diaperinus, and Hermetia illucens. Journal of Agricultural and Food Chemistry. 65: 2275-2278.

Jensen, L.D., Miklos, R., Dalsgaard, T.K., Heckmann, L.H. and Nørgaard, J.V., 2019. Nutritional evaluation of common (Tenebrio molitor) and lesser (Alphitobius diaperinus) mealworms in rats and processing effect on the lesser mealworm. Journal of Insects as Food and Feed 5: 257-266. https://doi.org/10.3920/JIFF2018.0048 
Jing, X. and Behmer, S.T., 2020. Insect sterol nutrition: physiological mechanisms, ecology, and applications. Annual Review of Entomology 65: 251-271.

Jones, L.D., Cooper, R.W. and Harding, R.S., 1972. Composition of mealworm Tenebrio molitor larvae. The Journal of Zoo Animal Medicine 3: 34-41.

Kaspari, M., 1991. Prey preparation as a way that grasshopper sparrows (Ammodramus savannarum) increase the nutrient composition of their prey. Behavioral Ecology 2: 234-241.

Kaya, M., Baran, T., Erdoğan, S., Menteş, A., Aşan Özüsağlam, M. and Çakmak, Y.S., 2014. Physicochemical comparison of chitin and chitosan obtained from larvae and adult Colorado potato beetle (Leptinotarsa decemlineata). Materials Science and Engineering: C 45: 72-81.

Kazimírová, M. and Ortel, J., 2000. Metal accumulation by Ceratitis capitata (Diptera) and transfer to the parasitic wasp Coptera occidentalis (Hymenoptera). Environmental Toxicology and Chemistry 19: 1822-1829.

Kiiru, S.M., Kinyuru, J.N., Kiage, B.N. and Marel, A.K. 2020. Partial substitution of soy protein isolates with cricket flour during extrusion affects firmness and in vitro protein digestibility. Journal of Insects as Food and Feed 6: 169-177. https://doi.org/10.3920/ JIFF2019.0024

Kinyuru, J.N., Kenji, G.M., Muhoho, S.N. and Ayieko, M. 2010b. Nutritional potential of longhorn grasshopper (Ruspolia differens) consumed in Siaya district, Kenya. Journal of Agriculture, Science and Technology 12: 32-46.

Kinyuru, J.N., Kenji, G.M., Njoroge, S.M. and Ayieko, M. 2010a. Effect of processing methods on the in vitro protein digestibility and vitamin content of edible winged termite (Macrotermes subhylanus) and grasshopper (Ruspolia differens). Food Bioprocess Technology 3: 778-782.

Kodondi, K.K., Leclercq, M. and Gaudin-Harding, F., 1987. Vitamin estimations of three edible species of Attacidae caterpillars from Zaire. International Journal of Vitamin and Nutrition Research 57: 333-334.

Köhler, R., Irias-Mata, A., Ramandey, E., Purwestri, R. and Biesalski, H.K., 2020. Nutrient composition of the Indonesian sago grub (Rhynchophorus bilineatus). International Journal of Tropical Insect Science 40: 677-686. https://doi.org/10.1007/s42690-020-00120-z

Köhler, R., Kariuki, L., Lambert, C. and Biesalski, H.K., 2019. Protein, amino acid and mineral composition of some edible insects from Thailand. Journal of Asia-Pacific Entomology 22: 372-378.

Komprda, T., Zornikova, G., Rozikova, V., Borkovcova, M. and Przywarova, A., 2013. The effect of dietary Salvia hispanica seed on the content of n-3 long-chain polyunsaturated fatty acids in tissues of selected animal species, including edible insects. Journal of Food Composition and Analysis 32: 36-43.

Koo, S.I., Currin, T.A., Johnson, M.G., King, E.W. and Turk, D.E., 1980. The nutritional value and microbial content of dried face fly pupae (Musca autumnalis (De Geer)) when fed to chicks. Poultry Science 59: 2514-2518.

Koštál, V., Urban, T., Rimnáčová, L., Berková, P., and Simek,, P., 2013. Seasonal changes in minor membrane phospholipid classes, sterols and tocopherols in overwintering insect, Pyrrhocoris apterus. Journal of Insect Physiology 59: 934-41.
Kouamé, B., Marcel, G., Brou André, K., Alassane, M., Koffi Gabouet, K. and Coulibally Séraphi, K., 2011. Détermination du taux optimal de farine d'asticots séchés dans le régime du rat en croissance. Journal of Animal and Plant Sciences 12: 1553-1559.

Kramarz, P., 1999. Dynamics of accumulation and decontamination of cadmium and zinc in carnivorous invertebrates. 1. The ground beetle, Poecilus cupreus L. Bulletin of Environmental Contamination and Toxicology 63: 531-537.

Kramer, K.J., Hopkins, T.L. and Schaefer, J., 1995. Applications of solids NMR to the analysis of insect sclerotized structures. Insect Biochemistry and Molecular Biology 25: 1067-1080.

Kulma, M., Kouřimská, L., Plachý, V., Božik, M., Adámková, A. and Vrabec, V., 2019. Effect of sex on the nutritional value of house cricket, Acheta domestica L. Food Chemistry 272: 267-272.

Landry, S., DeFoliart, G.R. and Sunde, M.L., 1986. Larval protein quality of six species of Lepidoptera (Saturniidae, Sphingidae, Noctuidae). Journal of Economic Entomology 79: 600-604.

Lease, H.M. and Wolf, B.O., 2010. Exoskeletal chitin scales isometrically with body size in terrestrial insects. Journal of Morphology 271: 759-768.

Lease, H.M. and Wolf, B.O., 2011. Lipid content of terrestrial arthropods in relation to body size, phylogeny, ontogeny and sex. Physiological Entomology 36: 29-38.

Levi, L., Ziv, T., Admon, A., Levavi-Sivan, B. and Lubzens, E., 2012. Insight into molecular pathways of retinal metabolism, associated with vitellogenesis in zebrafish. American Journal of Physiology Endocrinology and Metabolism 302: 626-644.

Liland, N.S., Biancarosa, I., Araujo, P., Biemans, D., Bruckner, C.G., Waagbø, R., Bente, E. Torstensen, B.E., and Lock, E.J., 2017. Modulation of nutrient composition of black soldier fly (Hermetia illucens) larvae by feeding seaweed-enriched media. PLoS ONE 12: $\mathrm{e} 0183188$.

Lin, S., Njaa, L.R., Eggum, B.O. and Shen, H., 1983. Chemical and biological evaluation of silk worm chrysalid protein. Journal of the Science of Food and Agriculture 34: 896-900.

Linder, P., 1919. Extraction of fat from small animals. Zoological Technology and Biology 7: 213-220.

Lindqvist, L., 1992. Accumulation of cadmium, copper, and zinc in five species of phytophagous insects. Environmental entomology 21: $160-163$.

Lindsay, G.J.H., Walton, M.J., Adron, J.W., Fletcher, T.C., Cho, C.Y. and Cowey, C.B., 1984. The growth of rainbow trout (Salmo gairdneri) given diets containing chitin and its relationship to chitinolytic enzymes and chitin digestibility. Aquaculture 37: 315-334.

Lipsitz, E.Y. and McFarlane, J.E., 1971. Analysis of lipid during the life cycle of the house cricket, Acheta domesticus. Insect Biochemistry 1: 446-460.

Liu, X., Chen, X., Wang, H., Yang, Q., Ur Rehman, K., Li, W., Cai, M., Li, Q., Mazza, L., Zhang, J., Yu, Z., and Zheng, L., 2017. Dynamic changes of nutrient composition throughout the entire life cycle of black soldier fly. PLoS ONE 12: e0182601.

Longvah, T., Mangthya, K. and Ramulu, P., 2011. Nutrient composition and protein quality evaluation of eri silkworm (Samia racinii) prepupae and pupae. Food Chemistry 128: 400-403. 
Madariaga, M.A., Mata, F., Municio, A.M. and Ribera, A. 1971. Effect of the lipid composition of the larval diet on the fatty acid composition during development of Ceratitis capitata. Insect Biochemistry 2: 249-256.

Madibela, O.R., Seitiso, T.K., Thema, T.F. and Letso, M., 2007. Effect of traditional processing methods on chemical composition and in vitro true dry matter digestibility of the mopanie worm (Imbrasia belina). Journal of Arid Environments 68: 492-500.

Makkar, H.P.S., Tran, G., Heuze, V. and Ankers, P., 2014: State-ofthe-art on use of insects as animal feed. Animal Feed Science and Technology 197: 1-33.

Maroni, G. and Watson, D., 1985. Uptake and binding of cadmium, copper and zinc by Drosophila melanogaster larvae. Insect Biochemistry 15: 55-63.

Marono, S., Piccolo, G., Loponte, R., Di Meo, C., Attia, Y.A., Nizza, A. and Bovera, F., 2015. In vitro crude protein digestibility of Tenebrio molitor and Hermetia illucens insect meals and its correlation with chemical composition traits. Italian Journal of Animal Sciences 14: 338-343.

Maryanski, M., Kramarz, P., Laskowski, R. and Niklinska, M., 2002. Decreased energetic reserves, morphological changes and accumulation of metals in carabid beetles (Poecilus cupreus L.) exposed to zinc-or cadmium-contaminated food. Ecotoxicology 11: 127-139.

Massie, H.R., Williams, T.R. and DeWolfe, L.K., 1989. Changes in taurine in aging fruit flies and mice. Experimental Gerontology 24: 57-65.

McComb, A., 2010. Evaluation of vitamin A supplementations for captive amphibian species. MSc thesis, North Carolina State University, Raleigh, North Carolina, 129 pp.

Megido, R.C., Poelaert, C., Ernens, M., Liotta, M., Blecker, C., Danthine, S., Tyteca, E., Haubruge, E., Alabi, T., Bindelle, J. and Francis, F., 2018. Effect of household cooking techniques on the microbiological load and the nutritional quality of mealworms (Tenebrio molitor $\mathrm{L}$. 1758). Food Research International 106: 503-508.

Mlček, J., Adámková, A., Adámek, M., Borkovcová, M., Bednářová, M. and Knížková, I., 2019. Fat from Tenebrionidae bugs - sterols content, fatty acid profiles, and cardiovascular risk indexes. Polish Journal of Food Nutrition Sciences 69: 247-254

Moussian, B., 2010. Recent advances in understanding mechanisms of insect cuticle differentiation. Insect Biochemistry and Molecular Biology 40: 363-375.

Mwangi, M.N., Oonincx, D.G.A.B., Stouten, T., Veenenbos, M., MelseBoonstra, A., Dicke, M. and Van Loon, J.J., 2018. Insects as sources of iron and zinc in human nutrition. Nutrition Research Reviews 31: 248-255.

Nakagaki, B.J., Sunde, M.L. and Defoliart, G.R., 1987. Protein quality of the house cricket, Acheta domesticus, when fed to broiler chicks. Poultry Science 66: 1367-1371.

National Research Council (NRC), 1994. Nutrient requirements of poultry. Ninth Edition. National Academy Press, Washington, DC, USA, $157 \mathrm{pp}$.

National Research Council (NRC), 2011. Nutrient requirements of fish and shrimp. National Academy Press, Washington, DC, USA, $376 \mathrm{pp}$.
National Research Council (NRC), 2012. Nutrient requirements of Swine. Eleventh Edition. National Academy Press, Washington, DC, USA, 420 pp.

Nestel, D., Papadopoulos, N.T., Liedo, P., Gonzales-Ceron, L. and Carey, J.R., 2005. Trends in lipid and protein contents during medfly aging: An harmonic path to death. Archives of Insect Biochemistry and Physiology 60: 130-139.

Newbrey, J.L., Paszkowski, C.A. and Dumenko, E.D., 2013. A comparison of natural and restored wetlands as breeding bird habitat using a novel yolk carotenoid approach. Wetlands 33: 471-482.

Nishimune, T., Watanabe, Y., Okazaki, H. and Akai, H., 2000. Thiamin is decomposed due to Anaphe spp. entomophagy in seasonal ataxia patients in Nigeria. Journal of Nutrition 130: 1625-1628.

Noland, J.L. and Baumann, C.A. 1949. Requirement of the German cockroach for choline and related compounds. Experimental Biology and Medicine 70: 198-201.

Nyangena, D.N., Mutungi, C., Imathiu, S., Kinyuru, J., Affognon, H., Ekesi, S., Nakimbugwe, D. and Fiaboe, K.K., 2020. Effects of traditional processing techniques on the nutritional and microbiological quality of four edible insect species used for food and feed in East Africa. Foods 9: 574.

Olson, J.A., 1989. Provitamin A function of carotenoids: the conversion of beta-carotene into vitamin A. Journal of Nutrition 119: 105-108.

Omotoso, O.T. 2006. Nutritional quality, functional properties and anti-nutrient compositions of the larva of Cirina forda (Westwood) (Lepidoptera: Saturniidae). Journal of Zhejiang University Science B 7: 51-55.

Onifade, A.A., Oduguwa, O.O., Fanimo, A.O., Abu, A.O., Olutunde, T.O., Arije, A. and Babatunde, G.M., 2001. Effects of supplemental methionine and lysine on the nutritional value of housefly larvae meal (Musca domestica) fed to rats. Bioresource Technology 78: 191-194.

Oonincx, D.G.A.B and Dierenfeld, E.S., 2012. An investigation into the chemical composition of alternative invertebrate prey. Zoo Biology 31: 40-54.

Oonincx, D.G.A.B and Van der Poel, A.F., 2011. Effects of diet on the chemical composition of migratory locusts (Locusta migratoria). Zoo Biology 30: 9-16

Oonincx, D., Bosch, G., Van Der Borght, M., Smets, R., Gasco, L., Fascetti, A., Yu, Z., Johnson, V., Tomberlin, J.K. and Finke, M., 2019b. A cross-laboratory study on analytical variability of amino acid content in three insect species. In: Book of Abstracts of the $70^{\text {th }}$ Annual Meeting of the European Federation of Animal Science. Wageningen Academic Publishers, Wageningen, the Netherlands, p. 327.

Oonincx, D.G.A.B, Laurent, S., Veenenbos, M.E. and Van Loon, J.J A., 2019a. Dietary enrichment of edible insects with omega 3 fatty acids. Insect Science 27: 500-509. https://doi.org/10.1111/1744-7917.12669 Oonincx, D.G.A.B., Stevens, Y., Van den Borne, J.J.G.C., Van Leeuwen, J.P.T.M. and Hendriks, W.H., 2010. Effects of vitamin D3 supplementation and UVb exposure on the growth and plasma concentration of vitamin D3 metabolites in juvenile bearded dragons (Pogona vitticeps). Comparative Biochemistry and Physiology B 156: 122-128. 
Oonincx, D.G.A.B., Van Broekhoven, S., Van Huis, A. and Van Loon, J.J.A., 2015a. Feed conversion, survival and development, and composition of four insect species on diets composed of food byproducts. PLoS ONE 10: e0144601.

Oonincx, D.G.A.B., Van Keulen, P., Finke, M.D., Baines, F.M., Vermeulen, M. and Bosch, G., 2018. Evidence of vitamin D synthesis in insects exposed to UVb light. Scientific Reports 810807.

Oonincx, D.G.A.B., Van Leeuwen, J.P., Hendriks, W.H. and Van der Poel, A.F.B., 2015b. The diet of free-roaming Australian central bearded dragons (Pogona vitticeps). Zoo Biology 34: 271-277.

Ortiz, C., Weiss-Penzias, P.S., Fork, S. and Flegal, A.R., 2015. Total and monomethyl mercury in terrestrial arthropods from the central California coast. Bulletin of environmental contamination and toxicology 94: 425-430.

Ottoboni, M., Spranghers, T., Pinotti, L., Baldi, A., De Jaeghere, W. and Eeckhout, M., 2018. Inclusion of Hermetia illucens larvae or prepupae in an experimental extruded feed: process optimisation and impact on in vitro digestibility. Italian Journal of Animal Science 17: 418-427.

Oyarzun, S.E., Crawshaw, G.J. and Valdes, E.V., 1996. Nutrition of the tamandua: I. Nutrient composition of termites (Nasutitermes spp.) and stomach contents from wild tamanduas (Tamandua tetradactyla). Zoo Biology 15: 509-524.

Ozimek, L., Sauer, W.C., Kozikowski, V., Ryan, J.K., Jorgensen, H. and Jelen, P., 1985. Nutritive value of protein extracted from honey bees. Journal of Food Science 50: 1327-1329.

Paoletti, M.G., Norberto, L., Damini, R. and Musumeci, S., 2007. Human gastric juice contains chitinase that can degrade chitin. Annals of Nutrition and Metabolism 51: 244-251.

Paul, A., Frederich, M., Megido, R.C., Alabi, T., Malik, P., Uyttenbroeck, R., Francis, F., Blecker, C., Haubruge, E., Lognay, G. and Danthine, S., 2017. Insect fatty acids: a comparison from three Orthopteran and Tenebrio molitor L. larvae. Journal of Asia-Pacific Entomology 20: 337-240.

Payne, C.L.R., Scarborough, P., Rayner, M. and Nonaka, K., 2016. A systematic review of nutrient composition data available for twelve commercially available edible insects and comparison with reference values. Trends in Food Science and Technology 47: 69-77.

Payne, C.L.R., Umemura, M., Dube, S., Azuma, A., Takenaka, C. and Nonaka, K., 2015. The mineral composition of five insects as sold for human consumption in Southern Africa. African Journal of Biotechnology 14: 2443-2448.

Pearincott, J.V., 1960. Changes in lipid content during growth and metamorphosis of the house fly Musca domestica Linnaeus. Journal of Cellular and Comparative Physiology 55: 167-174.

Pennino, M., Dierenfeld, E.S. and Behler, J.L., 1991. Retinol, alphatocopherol, and proximate nutrient composition of invertebrates used as feed. International Zoo Yearbook 30: 143-149.

Pesti, G.M., Harper, A.E. and Sunde, M.L., 1979. Sulfur amino acid and methyl donor status of corn-soy diets fed to starting broiler chicks and turkey poults. Poultry Science 58: 1541-1547.

Phelps, R.J., Struthers, J.K. and Moyo, S.J., 1975. Investigations into the nutritive value of Macrotermes falciger (Isoptera: Termitidae). Zoologica Africana 10: 123-132.
Pieterse, E. and Pretorius, Q., 2014. Nutritional evaluation of dried larvae and pupae meal of the housefly (Musca domestica) using chemical and broiler-based biological assays. Animal Production Science 54: 347-355.

Poelaert, C., Despret, X., Sindic, M., Beckers, Y., Francis, F., Portetelle, D., Soyeurt, H., Théwis, A. and Bindelle, J., 2017. Cooking has variable effects on the fermentability in the large intestine of the fraction of meats, grain legumes, and insects that is resistant to digestion in the small intestine in an in vitro model of the pig's gastrointestinal tract. Journal of Agricultural and Food Chemistry 65: 435-444.

Poelaert, C., Francis, F., Alabi, T., Caparros Megido, R., Crahay, B., Bindelle, J. and Beckers, Y., 2018. Protein value of two insects, subjected to various heat treatments, using growing rats and the protein digestibility-corrected amino acid score. Journal of Insects as Food and Feed 4: 77-87. https://doi.org/10.3920/JIFF2017.0003

Postma, J.F., VanNugteren, P. and De Jong, M.B.B., 1996. Increased cadmium excretion in metal-adapted populations of the midge Chironomus riparius (Diptera). Environmental Toxicology and Chemistry: An International Journal 15: 332-339.

Proc, K., Bulak, P., Wiącek, D. and Bieganowski, A. 2020. Hermetia illucens exhibits bioaccumulative potential for 15 different elements - implications for feed and food production. Science of the Total Environment 723: 138125.

Punzo, F., 2003. Nutrient composition of some insects and arachnids. Florida Scientist 66: 84-98.

Purschke, B., Scheibelberger, R., Axmann, S., Adler, A. and Jäger, H., 2017. Impact of substrate contamination with mycotoxins, heavy metals and pesticides on growth performance and composition of black soldier fly larvae (Hermetia illucens) for use in the feed and food value chain. Food Additives and Contaminants: Part A 34: 1410-1420.

Ramos-Elorduy, J., Gonzalez, E.A., Hernandez, A.R. and Pino, J.M., 2002. Use of Tenebrio molitor (Coleoptera: Tenebrionidae) to recycle organic wastes and as feed for broiler chickens. Journal of Economic Entomology 95: 214-220.

Ramsay, S.L. and Houston, D.C., 2003. Amino acid composition of some woodland arthropods and its implications for breeding tits and other passerines. Ibis 145: 227-232.

Rao, P.U., 1994. Chemical composition and nutritional evaluation of spent silk worm pupae. Journal Agriculture and Food Chemistry 42: 2201-2203.

Raubenheimer, D. and Rothman, J.M. 2013. Nutritional ecology of entomophagy in humans and other primates. Annual Review of Entomology 58: 141-160.

Reichle, D.E., Shanks, M.H. and Crossley, D.A., 1969. Calcium, potassium, and sodium content of forest floor arthropods. Annals of the Entomological Society of America 62: 57-62.

Rho, M.S. and Lee, K.P., 2014. Geometric analysis of nutrient balancing in the mealworm beetle, Tenebrio molitor L. (Coleoptera: Tenebrionidae). Journal of Insect Physiology 71: 37-45.

Riddick, E.W., 2014. Insect protein as a partial replacement for fishmeal in the diets of juvenile fish and crustaceans. In: Morales-Ramos, J.A., Rojas, M.G. and Shapiro, D.A. (eds) Mass production of beneficial organisms invertebrates and entomopathogens. Elsevier, Waltham, MA, USA, pp 565-582. 
Roe, R.M., Clifford, C.W. and Woodring, J.P., 1980. The effect of temperature on feeding, growth, and metabolism during the last larval stadium of the female house cricket, Acheta domesticus. Journal of Insect Physiology 26: 639-644.

Roe, R.M., Clifford, C.W. and Woodring, J.P., 1985. The effect of temperature on energy distribution during the last-larval stadium of the female house cricket, Acheta domesticus. Journal of Insect Physiology 31: 371-378.

Roseland, C.R., Grodowitz, M.J., Kramer, K.J., Hopkins, T.L. and Broce, A.B., 1985. Stabilization of mineralized and sclerotized puparial cuticle of muscid flies. Insect Biochemistry 15: 521-528.

Rudel, L.L., Parks, J.S., Hedrick, L., Thomas, M. and Willifors, K. 1998. Lipoprotein and cholesterol metabolism in diet-induced coronary artery atherosclerosis in primates. Role of cholesterol and fatty acids. Progress in Lipid Research 37: 353-370.

Rumpold, B.A. and Schluter, O.K., 2013a. Nutritional composition and safety aspects of edible insects. Molecular Nutrition Food Research 57: 802-823.

Rumpold, B.A. and Schluter, O.K., 2013b. Potential and challenges of insects as an innovative source for food and feed production. Innovative Food Science and Emerging Technologies 17: 1-11.

Sabolová, M., Adámková, A., Kouřimská, L., Chrpová, D. and Pánek, J., 2016. Minor lipophilic compounds in edible insects. Potravinarstvo 10: 400-406.

Sanchez-Muros, M.J., Barroso, F.G. and De Haro, C., 2016. Brief summary of insect usage as an industrial animal feed/feed ingredient. In: Dorsey, A.T., Morales-Ramos, J.A. and Rojas, M.G. (ed) Insects as sustainable food ingredients production, processing and food applications. Elsevier, Waltham, MA, USA, pp 273-309.

Sanchez-Muros, M.J., Barroso, F.G. and Manzano-Agugliaro, F., 2014. Insect meal as renewable source of food for animal feeding: a review. Journal of Cleaner Production 65: 16-27.

Santos Oliveira, J.F., Passos De Carvalho, J., Bruno De Sousa, R.F.X. and Simao, M.M., 1976. The nutritional value of four species of insects consumed in Angola. Ecology of Food and Nutrition 5: 91-97.

Schaefer, C.H., 1968. The relationship of the fatty acid composition of Heliothis zea larvae to that of its diet. Journal of Insect Physiology 14: 171-178.

Schiavone, A., De Marco, M., Martínez, S., Dabbou, S., Renna, M., Madrid, J., Hernandez, F., Rotolo, L., Costa, P., Gai, F. and Gasco, L., 2017. Nutritional value of a partially defatted and a highly defatted black soldier fly larvae (Hermetia illucens L.) meal for broiler chickens: apparent nutrient digestibility, apparent metabolizable energy and apparent ileal amino acid digestibility. Journal of Animal Science and Biotechnology 8: 51. https://doi.org/10.1186/s40104017-0181-5

Schmitt, E., Belghit, I., Johansen, J., Leushuis, R., Lock, E.J., Melsen, D., Shanmugam, R.K.R., Van Loon, J. and Paul, A., 2019. Growth and safety assessment of feed streams for black soldier fly larvae: a case study with aquaculture sludge. Animals 9: 189. https://doi. org/10.3390/ani9040189
Seki, T., Isono, K., Ozaki, K., Tsukahara, Y., Shibata-Katsuta, Y., Ito, M., Irie, T. and Katagiri, M., 1998. The metabolic pathway of visual pigment chromophore formation in Drosophila melanogaster alltrans (3S)-3-hydroxyretinal is formed from all-trans retinal via (3R)-3-hydroxyretinal in the dark. European Journal of Biochemistry 257: 522-527.

Shin, C.S., Kim, D.Y. and Shin, W.S., 2019. Characterization of chitosan extracted from mealworm beetle (Tenebrio molitor, Zophobas morio) and rhinoceros beetle (Allomyrina dichotoma) and their antibacterial activities. International Journal of Biological Macromolecules 125: 72-77.

Sonmez, E. and Gulel, A., 2008. Effects of different temperatures on the total carbohydrate, lipid and protein amounts of the bean beetle, Acanthoscelides obtectus Say (Coleoptera: Bruchidae). Pakistan Journal of Biological Sciences 11: 1803-1808.

Spranghers, T., Ottoboni, M., Klootwijk, C., Ovyn, A., Deboosere, S., De Meulenaer, B., Michiels, J., Eeckhout, M., De Clercq, P. and De Smet, S., 2017. Nutritional composition of black soldier fly (Hermetia illucens) prepupae reared on different organic waste substrates. Journal of the Science of Food and Agriculture 97: 2594-2600.

Ssepuuya, G., Mukisa, I.M. and Nakimbugwe, D., 2017. Nutritional composition, quality, and shelf stability of processed Ruspolia nitidula (edible grasshoppers). Food Science \& Nutrition 5: 103-112.

St-Hilaire, S., Cranfill, K., McGuire, M.A., Mosley, E.E., Tomberlin, J.K., Newton, L., Sealey, W., Sheppard, C. and Irving, S., 2007. Fish offal recycling by the black soldier fly produces a foodstuff high in omega-3 fatty acids. Journal of the World Aquaculture Society 38: 309-313.

Starčević, K., Gavrilović, A., Gottstein, Z. and Mašek, T., 2017. Influence of substitution of sunflower oil by different oils on the growth, survival rate and fatty acid composition of Jamaican field cricket (Gryllus assimilis). Animal Feed Science and Technology 228: 66-71.

Strobel, S., Roswag, A., Becker, N.I., Trenczek, T.E. and Encarnação, J.A., 2013. Insectivorous bats digest chitin in the stomach using acidic mammalian chitinase. PLoS ONE 8: e72770.

Studier, E.H. and Sevick, S.H., 1992. Live mass, water content, nitrogen and mineral levels in some insects from south-central lower Michigan. Comparative Biochemistry and Physiology A 103: 579-595.

Surendra, K.C., Olivier, R., Tomberlin, J.K., Jha, R. and Khanal, S.K. 2016. Bioconversion of organic wastes into biodiesel and animal feed via insect farming. Renewable Energy 98: 197-202.

Sushchik, N.N., Gladyshev, M.I., Moskvichova, A.V., Makhutova, O.N. and Kalachova, G.S. 2003. Comparison of fatty acid composition in major lipid classes of the dominant benthic invertebrates of the Yenisei river. Comparative Biochemistry and Physiology B 134: 111-122.

Sushchik, N.N., Yurchenko, Y.A., Gladyshev, M.I., Belevich, O.E., Kalachova, G.S. and Kolmakova, A.A., 2013. Comparison of fatty acid contents and composition in major lipid classes of larvae and adults of mosquitoes (Diptera: Culicidae) from a steppe region. Insect Science 20: 585-600. 
Svoboda, J., Schiff, N. and Feldlaufer, M., 1995. Sterol composition of three species of sawflies (Hymenoptera: Symphyta) and their dietary plant material. Experientia 51: 150-152.

Tabata, E., Kashimura, A., Kikuchi, A. Masuda, H., Miyahara, R., Hiruma, Y., Wakita, S., Ohno, M., Sakaguchi, M., Sugahara, Y., Matoska, V., Bauer, P.O. and Oyama, F., 2018. Chitin digestibility is dependent on feeding behaviors, which determine acidic chitinase mRNA levels in mammalian and poultry stomachs. Scientific Reports 8: 1461. https://doi.org/10.1038/s41598-018-19940-8

Teffo, L.S., Toms, R.B. and Eloff, J.N., 2007. Preliminary data on the nutritional composition of the edible stink-bug, Encosternum delegorguei Spinola, consumed in Limpopo province, South Africa. South African Journal of Science 103: 434-436

Teotia, J.S. and Miller, B.F., 1973. Fly pupae as a dietary ingredient for starting chicks. Poultry Science 52: 1830-1835.

Teotia, J.S. and Miller, B.F., 1974. Nutritive content of house fly pupae and manure residue. British Poultry Science 15: 177-182.

Thompson, S.N., 1973. Review and comparative characterization of fatty-acid compositions of seven insect orders. Comparative Biochemistry and Physiology 45: 467-482.

Tietz, A. and Stern, N., 1969. Stearate desaturation by microsomes on the locust fat-body. FEBS Letters 2: 286-288.

Timmermans, K.R. and Walker, P.A., 1989. The fate of trace metals during the metamorphosis of chironomids (Diptera, Chironomidae). Environmental pollution 62: 73-85.

Tschirner, M. and Simon, A., 2015. Influence of different growing substrates and processing on the nutrient composition of black soldier fly larvae destined for animal feed. Journal of Insects as Food and Feed 1: 249-259. https://doi.org/10.3920/JIFF2014.0008

Ueckert, D.N., Yang, S.P. and Albin, R.C. 1972. Biological value of rangeland grasshoppers as a protein concentrate. Journal of Economic Entomology 65: 1286-1288.

Van Broekhoven, S., Oonincx, D.G.A.B., Van Huis, A. and Van Loon, J.J.A., 2015. Growth performance and feed efficiency of three edible mealworm species (Coleoptera: Tenebrionidae) on diets composed of organic by-products. Journal of Insect Physiology 73: 1-10.

Van der Fels-Klerx, H.J., Camenzuli, L., Van der Lee, M.K. and Oonincx, D.G.A.B., 2016. Uptake of cadmium, lead and arsenic by Tenebrio molitor and Hermetia illucens from contaminated substrates. PLoS ONE 11: e0166186.

Vijver, M., Jager, T., Posthuma, L. and Peijnenburg, W., 2003. Metal uptake from soils and soil-sediment mixtures by larvae of Tenebrio molitor (L.)(Coleoptera). Ecotoxicology and Environmental Safety 54: 277-289.

Vogt, K. and Kirschfeld, K., 1984. Chemical identity of the chromophore of fly visual pigment. Naturwissenschaften 71: 211-213.

Von Lintig, J., 2012. Metabolism of carotenoids and retinoids related to vision. Journal of Biological Chemistry 287: 1627-1634.

Wang, D., Zhai, S.W., Zhang, C.X., Bai, Y.Y., An, S.H. and Xu, Y.N., 2005. Evaluation on nutritional value of field crickets as a poultry feedstuff. Asian-Australasian Journal of Animal Sciences 18: 667-670.

Wang, D., Zhai, S.W., Zhang, C.X., Zhang, Q. and Chen, H., 2007. Nutrition value of the Chinese grasshopper Acrida cinerea (Thunberg) for broilers. Animal Feed Science and Technology 135: 66-74.
Wang, S. Y., Wu, L., Li, B. and Zhang, D., 2020. Reproductive potential and nutritional composition of Hermetia illucens (Diptera: Stratiomyidae) prepupae reared on different organic wastes. Journal of Economic Entomology 113: 527-537.

Whitaker, Jr., J.O., Dannelly, H.K. and Prentice, D.A., 2004. Chitinase in insectivorous bats. Journal of Mammalogy 85: 15-18.

Whitton, P.S., Strang, R.H.C. and Nicholson, R.A., 1987. The distribution of taurine in the tissues of some species of insects. Insect Biochemistry 17: 573-577.

WHO/FAO/UNU Expert Consultation, 2007. Protein and amino acid requirements in human nutrition. WHO Technical Reports Series 935. World Health Organization, Geneva, Switzerland.

Woods, M.J., Goosen, N.J., Hoffman, L.C. and Pieterse, E., 2020. A simple and rapid protocol for measuring the chitin content of Hermetia illucens (L.) (Diptera: Stratiomyidae) larvae. Journal of Insects as Food and Feed 6: 285-290. https://doi.org/10.3920/ JIFF2019.0030

Wu, G.X., Ye, G.E., Hu, C. and Cheng, J.A., 2006. Accumulation of cadmium and its effects on growth, development and haemolymph biochemical compositions in Boettcherisca peregrina larvae (Diptera: Sarcophagidae). Insect Science 13: 31-39.

Wu, N., Wang, X., Xu, X., Cai, R. and Xie, S., 2020. Effects of heavy metals on the bioaccumulation, excretion and gut microbiome of black soldier fly larvae (Hermetia illucens). Ecotoxicology and Environmental Safety 192: 110323.

Xia, Z., Wu, S., Pan, S. and Kim, J.M., 2012. Nutritional evaluation of protein from Clanis bilineata (Lepidoptera), an edible insect. Journal of the Science of Food and Agriculture 92: 1479-1482.

Yang, L.F., Siriamornpun, S. and Li, D., 2006. Polyunsaturated fatty acid content of edible insects in Thailand. Journal of Food Lipids 13: 277-285.

Yi, L., Lakemond, C.M.M., Sagis, L.M.C., Eisner-Schadler, V., Van Huis, A. and Van Boekel, M.A.J.S., 2013. Extraction and characterisation of protein fractions from five insect species. Food Chemistry 141: 3341-3348.

Zhang, Z., Song, X., Wang, Q. and Lu, X., 2012. Cd and Pb contents in soil, plants, and grasshoppers along a pollution gradient in Huludao City, Northeast China. Biological Trace Element Research 145: 403-410.

Zhang, Z.-S., Lu, X.-G., Wang, Q.-C. and Zheng, D.-M., 2009. Mercury, cadmium and lead biogeochemistry in the soil-plant-insect system in Huludao City. Bulletin of environmental contamination and toxicology 83: 255.

Zhou, J.R. and Erdman, J.W., 1995. Phytic acid in health and disease. Critical Reviews in Food Science and Nutrition 35: 495-508.

Zhou, X., Honek, A., Powell, W. and Carter, N., 1995. Variations in body length, weight, fat content and survival in Coccinella septempunctata at different hibernation sites. Entomologia Experimentalis et Applicata 75: 99-107.

Zhuang, P., Huiling, Z. and Wensheng, S., 2009. Biotransfer of heavy metals along a soil-plant-insect-chicken food chain: field study. Journal of Environmental Sciences 21: 849-853. 
